\title{
INTERVENÇÃO FONOAUDIOLÓGICA JUNTO À FAMÍLIA DURANTE UM PROGRAMA DE TRIAGEM AUDITIVA NEONATAL UNIVERSAL
}

Simone Virginia Vitti

Dissertação apresentada à Faculdade de Odontologia de Bauru, da Universidade de São Paulo, como parte dos requisitos para obtenção do título de Mestre em Fonoaudiologia, área de Fonoaudiologia.

\section{Bauru 2006}




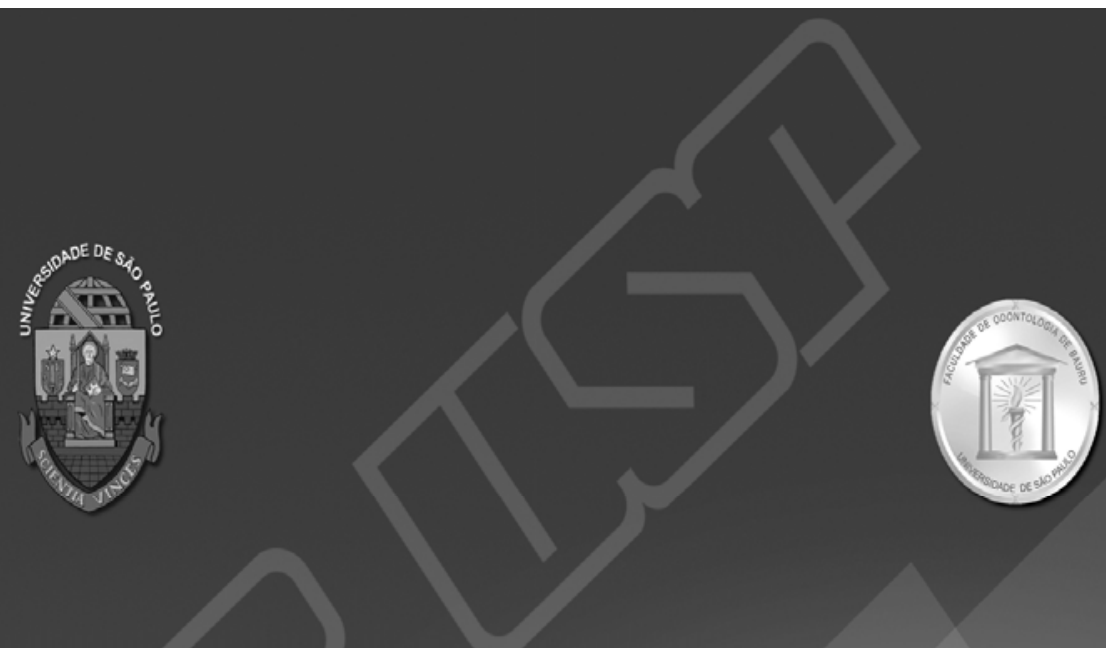

INTERVENCÃO FONOAUDIOLÓGICA JUNIO À FAMIILA DURANTE UM PROGRAMA DE TRIAGEM AUDITIVA NEONATAL UNIVERSAL

Simone Virginia Vitti

Dissertação apresentada à Faculdade de Odontologia de Bauru, da Universidade de São Paulo, como parte dos requisitos para obtenção do título de Mestre em Fonoaudiologia, área de Fonoaudiologia.

Orientadorat Profa. Dra Maria Cecilia Bevilacqua

\section{Bauru 2006}




\begin{tabular}{|c|c|}
\hline V835i & $\begin{array}{l}\text { Vitti, Simone Virginia } \\
\text { Intervenção fonoaudiológica junto à família durante um } \\
\text { programa de triagem auditiva neonatal universal / Simone } \\
\text { Virginia Vitti. -- Bauru, } 2006 . \\
\quad \text { xii } 101 \text { p.: il. ; } 30 \mathrm{~cm} .\end{array}$ \\
\hline & $\begin{array}{l}\text { Dissertação (Mestrado) -- Faculdade de Odontologia de } \\
\text { Bauru. Universidade de São Paulo. }\end{array}$ \\
\hline & Orientadora: Prof $^{\mathrm{a}} \mathrm{Dr}^{\mathrm{a}}$ Maria Cecília Bevilacqua \\
\hline
\end{tabular}

Autorizo, exclusivamente para fins acadêmicos e científicos, a reprodução total ou parcial desta dissertação/tese, por processos fotocopiadores e outros meios eletrônicos.

\section{Assinatura:}

Data:

\section{Comitê de Ética da FOB: Projeto de pesquisa aprovado em 26 de} outubro de 2005.

No do Protocolo: 118/2005. 

DADOS CURRICULARES

\section{SIMONE VIRGINIA VITTI}

07 de Outubro de 1969

$1990-1993$

$2001-2001$

$2001-2001$

$2001-2003$

$2002-2004$

Associações

$2005-2007$

\section{Nascimento}

Curso de Fonoaudiologia, Faculdade de Odontologia de Bauru, FOB-USP.

Curso de Pós-Graduação em Saúde Pública, em nível de especialização, na Universidade de Ribeirão Preto UNAERP - São Paulo.

Professora da Disciplina de Avaliação de Linguagem do Curso de Fonoaudiologia da Faculdade Afirmativo - Cuiabá - Mato Grosso.

Coordenadora do Curso de Fonoaudiologia do Centro Universitário de Várzea Grande - Mato Grosso.

Professora Convidada da Disciplina Saúde do Trabalhador do programa de pósgraduação em Saúde Pública da Universidade de Ribeirão Preto UNAERP.

Presidente da Associação de Ex-Alunos do Curso de Fonoaudiologia da Faculdade de Odontologia de Bauru - FOB/USP. 


\section{DED I C A T ÓR I A}

Dedico este trabalho:

As minhas queridas filhas, Bárbara e Verena, Ao meu marido Fábio e, Aos meus pais,

Que tudo me ensinaram como pessoa, esposa, mãe e família. 
"Se os pais forem bem cuidados as crianças ficarão bem". Dr. David Lutermann 


\section{AGRADECIMENTOS}

Gostaria de expressar minha imensa gratidão e carinho a todos que contribuíram de alguma forma para a realização desse trabalho, em especial...

À Prof ${ }^{a}$ Dr $^{a}$ Maria Cecília Bevilacqua, que constantemente tem sido um exemplo de determinação ao enfrentar os desafios da vida, pela sua dedicação, orientação e por ajudar a tornar realidade um dos meus sonhos profissionais, o título de mestre.

A todas as famílias que aceitaram participar deste estudo e pela confiança que, em mim, depositaram.

\section{À Prof ${ }^{a}$ Dr $^{a}$ Maria Angelina Nardi de Souza Martinez e à Prof ${ }^{a}$ Dr $^{a}$ Kátia} Alvarenga, pelas valiosas sugestões apresentadas na banca de qualificação.

Aos autores pesquisadores sobre o tema: preocupação familiar frente à triagem auditiva, que prontamente responderam aos meus e-mails, em especial à M.D. PhD. Betty Vohr, PhD. Leif Hergils e PhD Åsa Hergils, por terem enviado os questionários e autorizado a aplicação dos mesmos, viabilizando esse estudo.

Às minhas amigas da $1^{a}$ turma de Mestrado em Fonoaudiologia FOB-USP, alegremente agradeço, pelo companheirismo de todas e que fizeram deste programa de pós-graduação um ótimo lugar para estar.

Aos professores do Programa de Pós-Graduação do Mestrado em Fonoaudiologia por terem acreditado no теu potencial.

Às fonoaudiólogas da Clínica de Audiologia Infantil, Vanessa Sabino de Freitas, Tatiana Manfrini, Luzia Maria Ventura e Tatiana Mendes, pessoas especiais que prontamente me receberam durante a coleta de dados e muito me ajudaram.

Aos funcionários da Clínica de Fonoaudiologia, do Departamento de Fonoaudiologia e do Centro de Pesquisas Audiológicas, principalmente a Mary Mançãno de Lima, Marli Petenuci Ferrari e Karina Ferreira Barros Delazari pela ajuda sempre atendida com sorrisos e dedicação. 
Ao Lars Ole Geelmuyden Krook, pelo auxílio em encontrar as palavras certas no momento da tradução da língua suéca para a portuguesa-brasileira.

À minha querida amiga Marisa Pícarro Rezende, pelo companheirismo, pela amizade e por todos os momentos de colaboração que foram relevantes no desenvolvimento desse estudo.

À Adriana Vannuzini pela amizade de longos anos e pela colaboração na leitura dos artigos de língua alemã.

À Claudia Perrotta, pela minuciosa revisão do texto desse trabalho.

À Maristela Petenuci Ferrari pela ajuda na formatação do trabalho e por ter certeza que deste trabalho nasceu uma nova amizade.

Com muito amor no coração agradeço a minha mamãe, Virginia Salvador Vitti, e ao meu querido pai, Antonio Vitti, por constante ajuda na criação das minhas meninas durante todo o período do meu mestrado.

Aos meus irmãos, Wildson e William, por sempre estarem prontos a me ajudar nos momentos mais difíceis durante toda a minha vida, principalmente, nessa sonhada etapa profissional.

Especialmente agradeço, com todo o meu carinho e amor de esposa e mãe, aos meus queridos amores - Fábio, Bárbara e Verena - palavras são poucas pelos momentos em que estive ausente e que carinhosamente compreenderam e me apoiaram.

A Deus que iluminou meu caminho em todos os momentos da minha vida, nas alegrias e nas tristezas, sempre me enviando “Anjos Iluminados” para me auxiliar, quando necessário, ou mesmo para estarem presentes nos momentos de comemorações. 


\section{SUMÁRIO}

LISTA DE TABELAS ................................................................................. viii

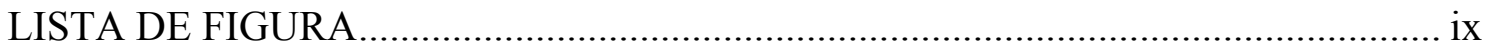

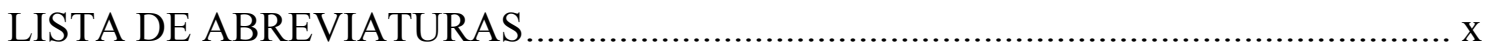

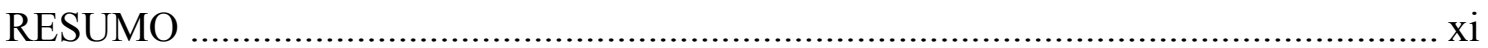

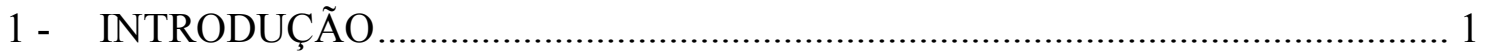

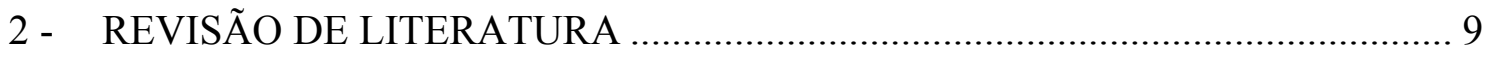

2.1 - Atitudes dos familiares diante da triagem auditiva neonatal universal $\mathrm{e}$ conhecimento que possuem sobre esse procedimento....................................... 11

2.2 - Impacto negativo da triagem auditiva na relação pais-bebê................................. 19

2.3 - Possíveis caminhos para acolher os familiares durante o processo de triagem

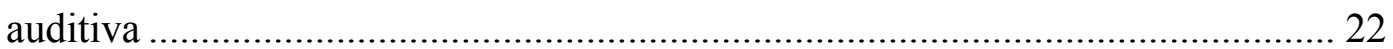

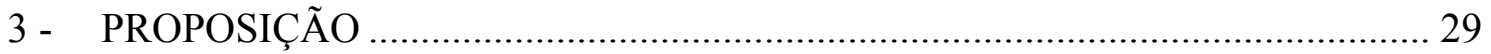

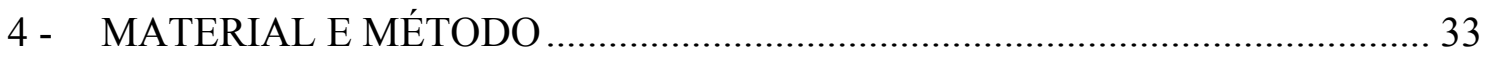

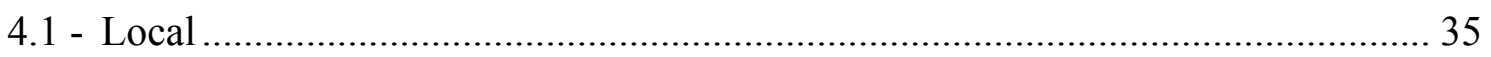

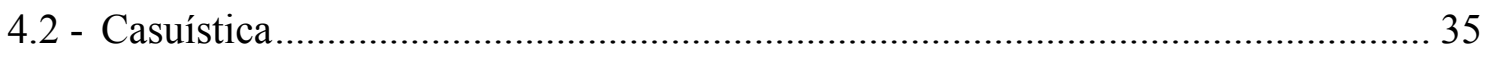

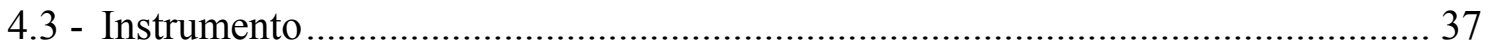

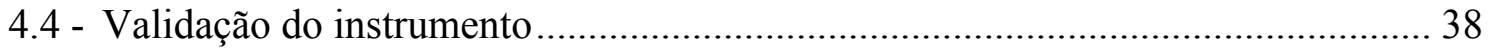

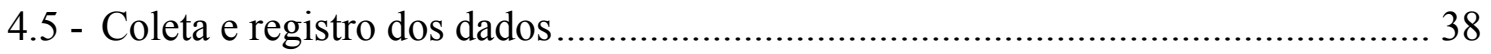

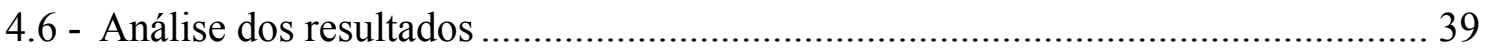

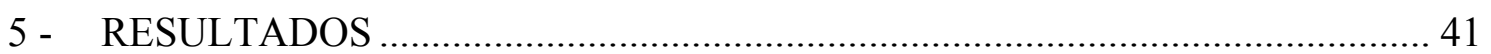

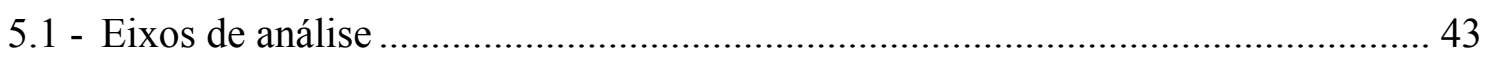

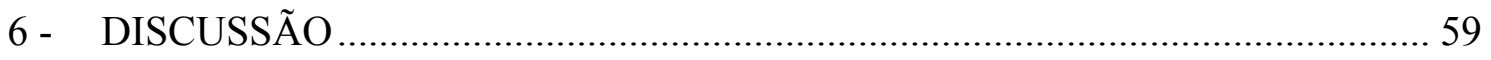

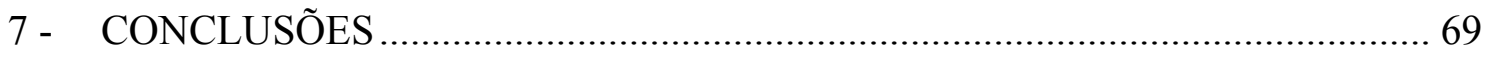

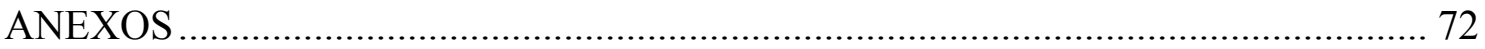

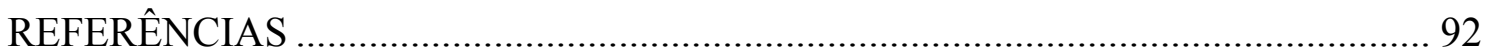

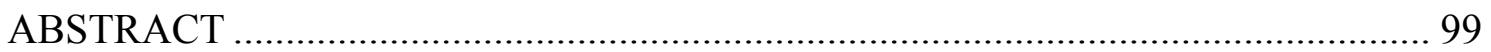




\section{LISTA DE TABELAS}

TABELA 1 - Distribuição da casuística segundo o grau de escolaridade dos pais ...... 44

TABELA 2 - Distribuição demográfica da casuística quanto ao número de filhos ..... 44

TABELA 3 - Distribuição demográfica da casuística referente aos dados gestacionais: tipo de parto e intervenção gestacional 45

TABELA 4 - Distribuição da característica da casuística referente aos bebês quanto à idade gestacional, ao peso ao nascimento e à faixa etária 45

TABELA 5 - Distribuição demográfica da casuística referente ao gênero dos bebês e à presença ou ausência de indicadores de risco. 46

TABELA 6 - Caracterização dos indicadores de risco dos bebês 46

TABELA 7 - Caracterização dos antecedentes familiares deficientes auditivos congênitos da casuística.

TABELA 8 - Grau de preocupação materna entre o teste e o reteste durante a TANU49

TABELA 9 - Grau de preocupação das mães em relação ao nível de escolaridade, número de filhos e indicador de risco.

TABELA 10 -Dados sobre a possibilidade de, em algum momento, a família ter pensado em "Não" levar o bebê para o diagnóstico audiológico 51

TABELA 11 -Conhecimento materno a respeito do teste da TANU 52

TABELA 12 -Caracterização do conhecimento materno frente ao reteste da TANU .. 54

TABELA 13 -Grau de preocupação das mães em relação ao momento em que souberam da triagem auditiva. 55

TABELA 14 -Conhecimento materno sobre a importância da audição do bebê e percepção quanto à audição do seu bebê 56 


\section{LISTA DE FIGURA}

FIGURA 1 -Fluxograma estabelecido para o atendimento do recém-nascido com e sem indicadores de risco para a deficiência auditiva no Projeto "Modelo de Saúde Auditiva no Recém-Nascido" no período de 2003 a 2005 ............... 8 


\section{LISTA DE ABREVIATURAS}

TAN - Triagem Auditiva Neonatal

TANU - Triagem Auditiva Neonatal Universal

EOA - Emissões Otoacústicas

EOAT - Emissões Otoacústicas Evocadas Transientes

EOADP - Emissões Otoacústicas Evocadas por Produto de Distorção

PEATE - Potencial Auditivo Evocado do Tronco Encefálico

VRA - Visual Reinforcement Audiometry

GATANU - Grupo de Apoio à Triagem Auditiva Neonatal Universal

JCIH - Joint Committe on Infant Hearing

AASI - Aparelho de Amplificação Sonora Individual

$\mathrm{dB}$ - Decibel

$\mathrm{Hz}-$ Hertz

OMS - Organização Mundial de Saúde

CBPAI - Comitê Brasileiro de Perdas Auditivas na Infância

NHI - NAtional Institutes of Health

RCP - Reflexo Cócleo Papebral

HDVT - Health visitor distraction test 


\section{RESUMO}

A triagem auditiva neonatal universal - TANU - tem sido recomendada no Brasil e no exterior como o principal instrumento para assegurar, nos primeiros anos de vida, o diagnóstico da deficiência auditiva. Nessa medida, o objetivo do presente estudo foi identificar o grau de preocupação e conhecimento a respeito desse procedimento por parte dos familiares, visando contribuir para o planejamento de ações que viabilizem estratégias ainda mais eficazes de orientações fonoaudiológicas. Também foi possível observar o quanto os pais sabem a respeito da audição do bebê, o que pode levar à criação de maneiras mais acolhedoras de acompanhamento e atenção às necessidades reais da família durante o diagnóstico audiológico. Para a pesquisa, foram então selecionadas, inicialmente, 42 famílias, das quais restaram trinta e oito cujos bebês não haviam passado no teste e reteste da TANU, realizados na maternidade Santa Isabel Bauru/SP, pelo projeto "Modelo de Saúde Auditiva no Recém-nascido". A coleta de dados e o registro foram realizados na Clínica de Audiologia Infantil do Departamento de Fonoaudiologia da FOB-USP, Bauru/SP, por meio da aplicação de um instrumento integralmente adaptado, tomando por base dois questionários: o Rhode Island Hearing Screen Program Questionnarie, aplicado em Rhode Island Hearing Assesment Program; e o questionário aplicado por HERGILS; HERGILS ${ }^{17}, 2000$ na University Hospital, Linköping-Suécia. Foram incluídas, ainda, seis questões pelos juízes que validaram o instrumento. Os resultados foram: houve um aumento significativo do grau de preocupação materna entre o teste e reteste da TANU $(p=0.002)$; a maior parte das participantes (50\%) soube da TANU após a alta hospitalar, 34\% durante a internação e $16 \%$ antes da internação hospitalar; 55\% informaram que não sabiam qual profissional havia realizado a TANU; $100 \%$ declararam ser favoráveis ao programa de TANU, sendo que, destas, 53\% mostraram-se insatisfeitas com as informações recebidas, tanto sobre os objetivos como sobre as conseqüências da avaliação. O presente estudo confirmou os resultados de outras pesquisas que ressaltam a importância dos programas de Saúde Auditiva no sentido de assegurar que as famílias compreendam a necessidade da TANU, bem como a continuação do diagnóstico audiológico e intervenção precoce, quando necessários.

Palavras-chave: Triagem neonatal. Testes auditivos. Família. Questionários. 



\section{1 - INTRODUÇÃO}





\section{1 - INTRODUÇÃO}

A deficiência auditiva é uma das alterações congênitas mais freqüentes em recém-nascidos, ocorrendo em aproximadamente 1-2 bebês por 1000 nascidos vivos (DECLAU et al. ${ }^{12}$, 2005). Devido a essa elevada prevalência, é considerada um problema de saúde pública pela Organização Mundial de Saúde (OMS) e tem sido objeto de inúmeras discussões, especialmente no que se refere às estratégias diagnósticas mais apropriadas, de modo que a intervenção possa ser fornecida precoce e adequadamente.

Sobre o momento mais adequado de se iniciar a indicação de amplificação e o processo terapêutico, encontramos na literatura diversos autores que consideram o primeiro ano de vida da criança como um período complexo, já que ocorrem muitas modificações morfológicas e funcionais no sistema nervoso que determinarão o desenvolvimento da linguagem e da fala. A privação da audição nessa fase poderá ocasionar não só uma inabilidade irreversível para perceber diferenças nos sons da fala, como também, prejudicar a aquisição da linguagem e, conseqüentemente, o desenvolvimento social, psíquico e educacional da criança (NORTHEN; DOWNS ${ }^{28}$, 1989).

De fato, os estudos mostram que crianças que foram diagnosticadas com perda auditiva antes dos seis meses de idade e, por conseguinte, iniciaram a intervenção desenvolveram-se mais do que aquelas diagnosticadas após um ano de idade. Ou seja: quanto mais cedo for o diagnóstico audiológico de perda auditiva, mais precocemente será a intervenção e melhor será o desenvolvimento (YOSHINAGA-ITANO et al. ${ }^{44}$, 1998).

Diante disso, a triagem auditiva neonatal universal - TANU - tem sido recomendada no Brasil e no exterior como o principal instrumento para assegurar o diagnóstico da deficiência auditiva logo nos primeiros meses de vida do bebê.

Para realizá-la, devem ser efetuados diversos exames, tanto objetivos como subjetivos. Dentre os primeiros, destacam-se as emissões otoacústicas (EOA), 
primeiramente descritas por $\mathrm{KEMP}^{21}$, em 1978. Este estudioso constatou a presença de energia acústica produzida na orelha interna de forma espontânea ou evocada por estímulos sonoros. Essa energia é captada de forma rápida, não-invasiva e, quando presente e registrada, indica função das células ciliadas internas presentes na cóclea normal (orelha interna). Pode-se, assim, realizar a triagem auditiva neonatal por meio desse exame objetivo, simples e não invasivo.

Mas há também que se considerar quais os recém-nascidos que necessitam de avaliação, se todos ou apenas aqueles que apresentam fatores de risco para a deficiência auditiva. Em 1993, WHITE; VOHR; BEHRS ${ }^{41}$, realizaram um estudo junto ao programa de triagem auditiva de Rhode Island, em 1850 recém-nascidos, sendo 1546 de berçário e 304 recém-nascidos de unidades de terapia intensiva (UTI) neonatal. Os autores constataram, então, que a prevalência de perda auditiva neurossensorial foi representada por 1,5 a 5,9 para cada 1000 recém-nascidos vivos e por 20 perdas auditivas condutivas para 1000 recém-nascidos vivos. A partir desse estudo, a triagem auditiva neonatal universal - TANU - passou a ser recomendada a todos os recémnascidos, antes da alta hospitalar, e não apenas àqueles que apresentassem indicadores de risco (JCIH, 1994). Assim, o Women and Infant Hospital of Rodhe Island foi o primeiro programa a enfatizar a importância de realizar a triagem em todos os recémnascidos.

Em 1994, o JOINT COMMITTEE ON INFANT HEARING ${ }^{19}$ sugeriu, então, a substituição da nomenclatura "fatores de risco" para "indicadores de risco", e recomendou a TANU, a ser realizada por meio de duas técnicas fisiológicas: emissões otoacústicas (EOAE) e potencial evocado de tronco encefálico (PEATE).

No Brasil, em 1998, foi criado o Grupo de Apoio à Triagem Auditiva Neonatal Universal (GATANU), tendo como objetivos divulgar a importância da realização da TANU, assegurando o diagnóstico audiológico e a intervenção até os seis meses de idade, e sensibilizar os profissionais e a população para esse procedimento (CHAPCHAP $\left.{ }^{6}, 2005\right)$. Em 1999, foi criado o Comitê Brasileiro sobre Perdas Auditivas na Infância por um grupo envolvido na área do diagnóstico da surdez na infância, apresentando como finalidade a elaboração de recomendações sobre identificação, diagnóstico, manejo e reabilitação das perdas auditivas na infância. Essas 
recomendações têm como objetivo fazer com que as diretrizes propostas pelo Comitê sirvam para todos os programas já existentes.

Segundo a American Academy of Pediatrics ${ }^{1}$, 1999, todos os recémnascidos deveriam ser triados ao nascimento ou diagnosticados, no máximo, até os três meses de idade, sendo que, em caso de confirmação da deficiência auditiva, a criança deveria receber intervenção adequada e imediatamente, ou seja, até os seis meses de idade.

Para o JOINT COMMITTE ON INFANT HEARING ${ }^{20}$, 2000, todo o desenvolvimento do bebê que nasce com deficiência auditiva depende do tipo e grau da perda auditiva e, principalmente, da identificação precoce dessa perda, isto é, o diagnóstico audiológico deve ser feito até os três meses de idade e a intervenção iniciada até os seis meses de idade.

Com o objetivo de apresentar o programa de TANU no Brasil, CHAPCHAP; SEGRE 7 , 2001, realizaram um estudo referente ao teste de EOA transiente (EOAet) e a prevalência da perda auditiva. As autoras triaram $4.196(90,6 \%)$ recém-nascidos antes da alta hospitalar; destes, $4.123(98,2 \%)$ apresentaram audição normal e 73 não apresentaram resultados dentro da normalidade, sendo então acompanhados depois da alta hospitalar. Neste período de acompanhamento, 60 (82\%) bebês apresentaram audição normal e 10 tiveram confirmada a deficiência auditiva. As autoras concluíram que o programa TANU utilizando a EOAet é um método viável e exato para detectar perdas auditivas precocemente e constataram que a porcentagem dessa deficiência para a população estudada foi de 2,3 para 1000 recém-nascidos vivos. Segundo as autoras, provavelmente devido à participação e às habilidades práticas da execução da triagem, o programa ainda conseguiu baixa taxa de resultados falsopositivos, outro aspecto de extrema importância e que gera certa polêmica na literatura que aborda a TANU, como se verá mais adiante.

Em setembro de 2004 o MINISTÉRIO DA SAÚDE ${ }^{25}$, publicou as portarias $n^{\text {o }} 2073 /$ GM (28/09/2004), no $587(07 / 10 / 2004)$ e $n^{\circ} 589(08 / 10 / 2004)$ relacionadas à atenção à saúde auditiva, normatizando a criação da Política Nacional de Atenção à Saúde Auditiva, prevendo ações que englobam todos os níveis de atenção básica, média e de alta complexidade. 
Porém, em estudo sobre maternidades que fazem a TANU no Brasil, CHAPCHAP $^{6}$, 2005, relatou que, dentre as 5.800 pesquisadas, havia somente 237 serviços estruturados em triagem auditiva neonatal e cadastrados no GATANU, um número muito baixo para o tamanho territorial do país, e desses a maioria são prestados por instituições privadas. De modo que a autora sugere a importância de aumentar a consciência coletiva para o problema da surdez no Brasil, além da divulgação da necessidade de realização da TANU, assegurando o diagnóstico e a intervenção até os seis meses de idade e, sobretudo, padronizando e normatizando o protocolo da TANU.

Desde setembro do ano de 2003, o Departamento de Fonoaudiologia da Faculdade de Odontologia de Bauru-USP desenvolve o Projeto "Modelo de Saúde Auditiva no Recém-nascido" em parceria com a Maternidade Santa Isabel de Bauru/SP. Esse programa defende o diagnóstico até os três meses de idade e o início da intervenção terapêutica até os seis meses $\left(\mathrm{JCIH}^{20}, 2000\right.$; $\left.\mathrm{CBPAI}^{9}, 2000 ; \mathrm{NHI}^{26}, 1993\right)$.

O projeto está credenciado no Sistema Único de Saúde (SUS) como centro de alta complexidade no atendimento ao deficiente auditivo e se desenvolve metodologicamente em: programa de Triagem Auditiva Neonatal Universal (TANU); diagnóstico audiológico; intervenção com adaptação, doação de aparelho de amplificação sonoro individual (AASI) e (re) habilitação auditiva.

O fluxograma do programa TANU pode ser visualizado na Figura 1 que evidencia toda a trajetória do projeto "Modelo de Saúde Auditiva no Recém-Nascido". Por meio deste, destacamos que, quando não passam no reteste da TANU, os bebês são encaminhados para realizarem o diagnóstico audiológico na Clínica de Audiologia Infantil do Curso de Fonoaudiologia da Faculdade de Odontologia de Bauru-USP, centro de referência da deficiência auditiva. Esse projeto também possui uma logística de preenchimento do prontuário do recém-nascido, bem como o fluxo de encaminhamentos para o diagnóstico audiológico, acompanhamento e orientações.

O processo diagnóstico acontece, geralmente, entre o primeiro e terceiro meses de vida do bebê e compreende os seguintes procedimentos: timpanometria, reflexo acústico, EOAet, RCP, neurodiagnóstico por meio dos PEATE somente para os bebês com indicador de risco para deficiência auditiva, e pesquisa de limiar por meio do PEATE se houver ausência de EOAet ou reflexo acústico. Se for constatada audição 
normal e o bebê não apresentar indicador de risco para deficiência auditiva $\left(\mathrm{JCIH}^{20}\right.$, 2000), ele recebe alta, e a mãe é orientada quanto ao desenvolvimento auditivo, de linguagem e fala. Essa orientação é imprescindível na TANU, sendo realizada pela fonoaudióloga que atua no programa.

No entanto, pouco se tem estudado sobre a importância do acompanhamento da família durante todo processo do diagnóstico audiológico do bebê. Essa omissão pode ter implicações importantes na eficácia de todo o processo, que vai da triagem auditiva à intervenção audiológica. Torna-se fundamental, portanto, nos voltarmos para a família, já que todo o processo de desenvolvimento do recém-nascido será construído no núcleo familiar e na relação pais-bebê.

Diante disso, o propósito do presente estudo foi investigar a intervenção fonoaudiológica na perspectiva dos pais frente ao Programa de Triagem Auditiva Neonatal Universal, a fim de buscar subsídios para o planejamento de ações que viabilizem estratégias de orientações mais eficazes para o acompanhamento e acolhimento das famílias. Para tanto, seguimos a metodologia proposta pelo projeto "Modelo de Saúde Auditiva no Recém-nascido", respeitando a etapa de inclusão quando a família encontrava-se pela primeira vez à Clínica de Audiologia Infantil do Curso de Fonoaudiologia da Faculdade de Odontologia de Bauru-USP para o diagnóstico audiológico do seu bebê. 
Fluxograma do Projeto "Modelo de Saúde Auditiva no Recém-Nascido".

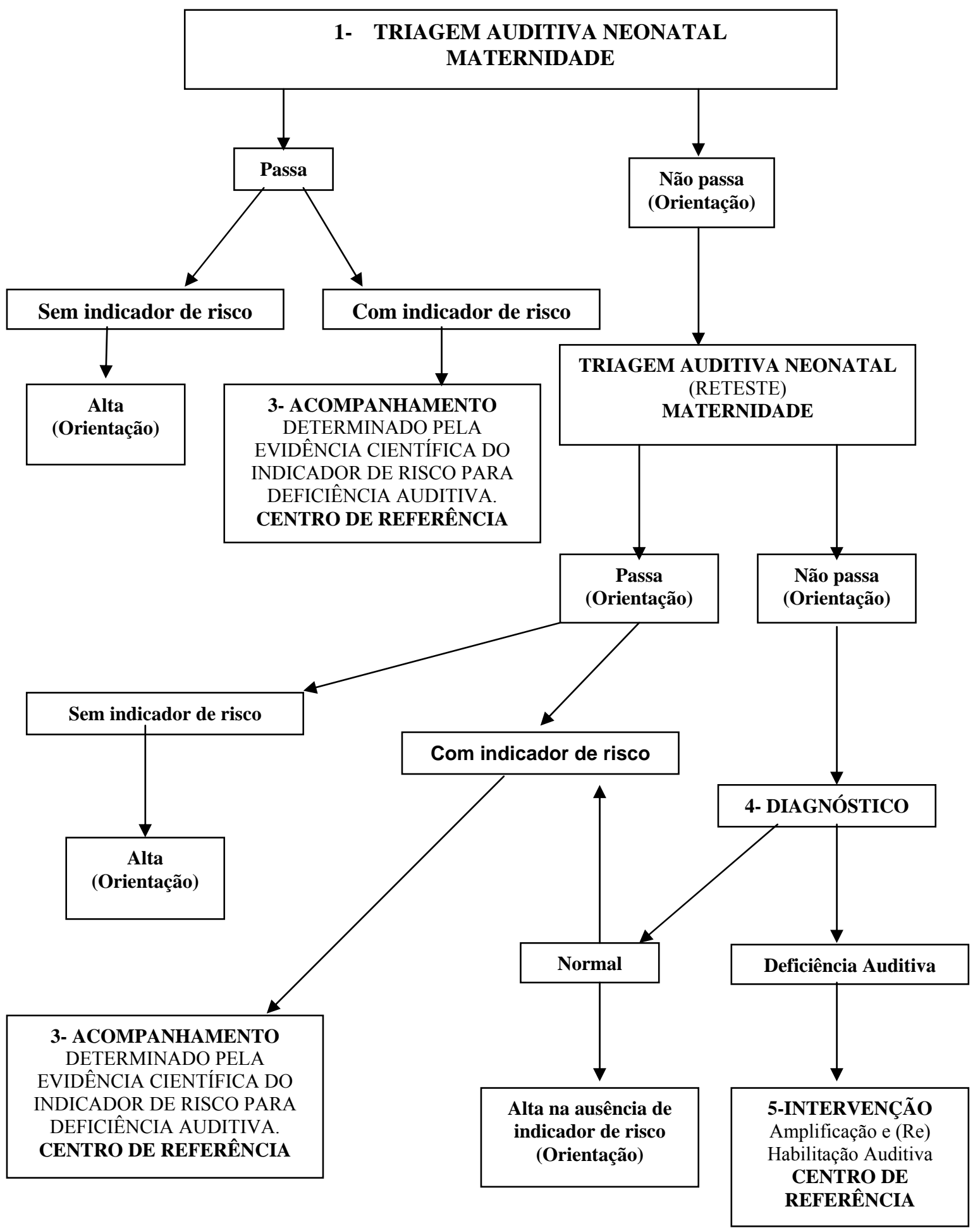

Figura 1 - Fluxograma estabelecido para o atendimento do recém-nascido com e sem indicadores de risco para a deficiência auditiva no Projeto "Modelo de Saúde Auditiva no Recém-Nascido" no período de 2003 a 2005 
2 - REVISÃO DE LITERATURA 



\section{2 - REVISÃO DE LITERATURA}

A revisão de literatura foi organizada em três partes:

2.1 - Atitudes dos familiares diante da triagem auditiva neonatal universal e conhecimento que possuem sobre esse procedimento;

2.2 - Impacto negativo da triagem auditiva na relação pais-bebê;

2.3 - Possíveis caminhos para acolher os familiares durante o processo de triagem auditiva.

Em função das características do presente estudo, é de extrema importância esclarecer que encontramos poucos trabalhos na literatura brasileira atual diretamente relacionados com o tema aqui abordado.

\section{1 - Atitudes dos familiares diante da triagem auditiva neonatal universal e conhecimento que possuem sobre esse procedimento}

Nos últimos dez anos, alguns pesquisadores têm se voltado para o estudo das atitudes dos familiares diante da TANU.

Uma das primeiras pesquisas sobre o tema no Brasil data de 1998 e foi realizada por OLIVEIRA; ZANELLI; MAINARDI ${ }^{29}$. Os autores partiram de uma amostra constituída por 240 mulheres internadas em uma maternidade, constatando o seguinte: apenas 31,5\% delas sabiam que a realização da TANU era possível e importante para a audição do bebê, sendo que 29,96 \% preferiam avaliar seus bebês em outra ocasião e $13,52 \%$ preferiram não realizá-la, alegando que não havia pessoas surdas na família. O estudo observou, então, que a população estudada era pouco informada corretamente sobre a TANU, sugerindo que fonoaudiólogos, pediatras, obstetras, entre outros profissionais da saúde, podem e devem orientar os pais quanto à 
importância desse procedimento, esclarecendo também a respeito das causas da deficiência auditiva.

Nessa mesma linha de pesquisa, LUTERMAN; KURTZER-WHITE ${ }^{22}, 1999$ enviaram um questionário, por correio, a 200 pais que sabiam que suas crianças tinham perda auditiva com o intuito de avaliar as conseqüências desse diagnóstico na família. Dos 75 pais que responderam, 58 (83\%) afirmaram que seus filhos não foram diagnosticados no período neonatal, mas que gostariam que isso tivesse ocorrido, e 51 $(82 \%)$ indicaram a necessidade de maior informação e condolência por parte do audiologista no momento da comunicação do diagnóstico. Os autores concluíram que esses pais precisariam ter tido um tempo maior para processar seus sentimentos diante do problema, bem como mais informações sobre a própria deficiência. Também constataram a necessidade predominante de encontrarem-se com outros pais de crianças deficientes auditivas e concluíram que quem deve informar sobre as conseqüências da perda de audição é, preferencialmente, o audiologista.

Mais recentemente, em estudo retrospectivo, CLEMENS; DAVIS; BAILEY et al. ${ }^{8}, 2000$, abordaram um outro aspecto de suma importância: a possibilidade de falso-positivo na TANU e as mudanças de atitudes da família frente a esse resultado. Analisaram, então, uma amostra de 5010 bebês que tinham sido triados por meio do exame de potencial evocado acústico (PEATE), constatando o seguinte: 9\% das mães cujos bebês primeiramente não passaram no teste, mas depois passaram no reteste disseram que trataram diferentemente seus filhos após o primeiro resultado; e 14\% relataram ansiedade mesmo com o resultado negativo do reteste. $\mathrm{O}$ reteste foi realizado após duas semanas do nascimento, sendo que $86 \%$ das mães não relataram ansiedade a respeito do processo, seis (12\%) relataram um pouco de ansiedade e somente uma mãe (2\%) relatou muita ansiedade, pois sua criança apresentou resultado falso-positivo no teste e reteste. Dos 5010 bebês triados, nove apresentaram perda auditiva - taxa de 1.8/1000. Quanto à finalidade do teste e o significado do resultado, 15\% das mães relataram que ambos não foram adequadamente explicados e $80 \%$ delas referiram ter ficado preocupadas com a audição de seus bebês antes do reteste. E sobre a atitude de outros membros da família, $91 \%$ das mães afirmaram que seus filhos não foram tratados diferentemente entre o teste e o reteste, e $9 \%$ relataram que alguns familiares falavam mais alto ou batiam as mãos para testar a audição dos bebês. 
Os autores descreveram três fatores que poderiam justificar a ansiedade dos pais: $1^{\circ}$. grau de instrução das mães; $2^{\circ}$. falta de conhecimento sobre a TANU; $3^{\circ}$. resultado falso-positivo, tanto no teste como no reteste. E concluíram que, mesmo que a ansiedade materna diante do resultado falso-positivo tenha sido pouco comum, antes da alta hospitalar é necessário orientar a família com clareza sobre a importância do reteste nos recém-nascidos e sobre o desenvolvimento auditivo. Uma das maneiras de minimizar o sentimento negativo dos pais a respeito da TANU seria, então, melhorar a orientação já durante o primeiro teste, pois a falta de compreensão sobre a finalidade deste e sobre o significado do resultado não passa foi comum.

O estudo de HERGILS; HERGILS ${ }^{17}$, 2000, sobre as atitudes e pensamentos dos familiares em relação à TANU utilizou como instrumento um questionário com cinco questões abertas, aplicado durante o acompanhamento na rotina hospitalar a 87 pais de crianças que tinham participado desse programa de triagem. Como resultado, os autores obtiveram o seguinte: $95 \%$ dos pais tiveram uma atitude positiva frente à triagem, $1 \%$ foram ambivalentes e 4\% foram negativos. Sobre a suficiência das informações fornecidas em relação ao teste, $77 \%$ responderam positivamente e $11 \%$ relataram que foram insuficientes, pois gostariam de ter recebido mais informações sobre a técnica de EOA.

$\mathrm{Na}$ primeira questão, "Qual foi a sua experiência a respeito da triagem auditiva neonatal?", 76 pais ficaram satisfeitos, três foram neutros, três não ficaram satisfeitos e um não lembrava. Desses pais, a maioria, 54, relatou ter tido uma experiência positiva e treze fizeram comentários negativos, sendo que, às vezes, mais de um comentário era feito pelos entrevistados. Com relação à segunda questão, “Com $a$ triagem auditiva surgiram algumas questões ou pensamentos?", 28 pais responderam positivamente, 14 responderam negativamente e 13 não responderam. Na questão de número três, "Você é favorável ou não a este teste? Por favor, explique", 79 pais declararam ser favoráveis, um foi ambivalente e um apresentou uma resposta neutra. $\mathrm{Na}$ quarta questão, "Você achou a informação dada a respeito do teste suficiente ou não? Você obteve respostas em eventuais perguntas?”, 64 relataram que as informações foram suficientes, seis responderam que não receberam uma informação satisfatória e nove relataram que a informação dada a respeito do teste não foi suficiente. Sobre se as eventuais perguntas foram respondidas, um pai não recordou, três não responderam, 10 
comentaram, espontaneamente, satisfação com as respostas recebidas e 11 relataram não ter recebido respostas para as suas perguntas. Finalmente, na questão de número cinco: "Você gostaria de fazer mais algum comentário?", 15 pais fizeram comentários positivos, dentre eles: a triagem auditiva neonatal é muito boa; detectar precocemente a perda auditiva é muito bom; o tratamento foi amável e positivo, entre outros; dois comentários foram neutros e quatro comentários foram negativos. A maioria dos pais, 72, não fez comentários.

Os autores concluíram que a maioria dos pais acredita que a TANU é positiva, sendo que aqueles cujos bebês passaram nos testes sentiram-se tranqüilizados, enquanto os pais das que apresentaram perda auditiva relataram ter sido muito importante a detecção e o encaminhamento para a habilitação precoce.

Já WEICHBOLD; WELZL-MULLER ${ }^{40}, 2000$ pesquisaram se a ansiedade materna frente ao resultado falso-positivo poderia ser um argumento contra a realização da TANU. Para confirmar ou não essa hipótese, os autores exploraram as atitudes das mães frente a esse procedimento, realizado antes da alta hospitalar, e o grau de ansiedade caso o resultado fosse falso-positivo. $O$ instrumento utilizado foi um questionário com cinco questões, dirigido a 75 mães. Dentre estas, 38 já sabiam sobre a triagem auditiva e, apesar da possibilidade de um resultado falso-positivo, 33 aceitaram realizá-la. Essa atitude positiva foi associada ao conhecimento sobre o teste e à possibilidade de presença durante a sua realização. Das 20 mães cujos bebês receberem resultado falso-positivo no primeiro teste, 15 informaram que não ficaram preocupadas, quatro ficaram um pouco preocupadas e somente duas declararam terem se preocupado muito. Do grupo de 15 mães cujos bebês não passaram no teste e reteste e foram encaminhados para diagnóstico audiológico, seis relataram que não estavam preocupadas, cinco um pouco preocupadas e quatro disseram estar muito preocupadas. Ainda nesse grupo de mães, 12 disseram ter sido suficientemente bem informadas sobre a TANU, enquanto três responderam que não receberam informações suficientes. Com relação à possibilidade de resultado falso-positivo no primeiro teste, apenas $10 \%$ das entrevistadas referiram preocupação. Entretanto, 27\% das mães cujos bebês tiveram falso-positivo no reteste relataram claramente estarem preocupadas com o resultado, além de manifestarem descrença a respeito da triagem auditiva. Esses sentimentos podem estar diretamente associados à falta de informação anterior ao teste, sendo 
necessário esclarecer então que a mãe pode estar presente durante a realização da triagem e que o diagnóstico audiológico precoce é extremamente importante. Os autores concluíram que o fato de a TANU causar preocupação materna "ocasional" deve ser compreendido não como um argumento negativo e sim como um convite para otimizála.

Para WEBER; DIEFENDORF ${ }^{41}$, 2001, pelo fato de o processo diagnóstico ser o período da confirmação ou da negação da deficiência auditiva, geralmente, causa extrema ansiedade na família. Assim, caso o bebê não tenha passado na triagem auditiva, os pais devem lidar com seu próprio estresse emocional, que pode perdurar mesmo após a perda auditiva ter sido descartada. Esse impacto emocional, que dura um longo tempo, é a base para ocorrer a "síndrome da criança vulnerável”; isto é, os pais tendem a tratar seus filhos como se estes fossem facilmente suscetíveis a acidentes ou problemas médicos, resultando em um comportamento superprotetor. Nessa perspectiva, o profissional deve sempre estar preparado para fornecer informações e apoio emocional à família quando o bebê for encaminhado para a triagem auditiva e/ou para o diagnóstico audiológico.

Em sua pesquisa sobre a triagem auditiva neonatal, YOSHINAGAITANO $^{43}$, 2001 ressaltou que esse procedimento é fundamental para identificar precocemente a perda auditiva congênita, resultando na intervenção precoce. Com isto, possibilita um desenvolvimento de linguagem e social dentro do padrão de normalidade até os cinco anos de vida, devido aos serviços apropriados de intervenção, disponibilizados imediatamente para as famílias. Esse estudo demonstrou que o nível de preocupação dos pais frente ao programa de triagem auditiva neonatal universal é considerado baixo, de 3 a 13\%, similar ao nível de estresse observado na população em geral. Assim, a disponibilização do programa de acompanhamento desde o início pode resultar mais rapidamente na solução do sofrimento, diminuindo o estresse da família e ocasionando, assim, a participação desta no desenvolvimento emocional, de linguagem e social da criança com perda auditiva.

Preocupando-se especificamente com a intervenção fonoaudiológica, em seu estudo MANFREDI ${ }^{24}, 2001$ obteve o índice de retornos de mães cujos bebês de risco apresentaram resultado negativo no exame de EOA a um programa de acompanhamento do desenvolvimento auditivo realizado antes da alta hospitalar. A autora também 
realizou um levantamento dos motivos pelos quais não ocorreram os retornos. A coleta foi feita em dois grupos - controle e experimental. O primeiro era composto de 39 mães (ou responsáveis) cujos bebês não realizaram o exame de EOA e não receberam intervenção fonoaudiológica até a data da consulta agendada na pós-alta. Já o grupo experimental incluía 60 mães (ou responsáveis) cujos bebês tinham realizado o exame de EOA com presença de resposta da cóclea em ambas as orelhas, sendo que, anteriormente à alta hospitalar, essas mães foram informadas sobre o resultado e orientadas a respeito do desenvolvimento auditivo, por meio da intervenção fonoaudiológica. Todas as participantes foram questionadas, via telefone, sobre a TANU e sobre a razão da ausência durante a triagem auditiva e o processo do diagnóstico.

A autora constatou que $30,8 \%$ das mães do grupo experimental sinalizaram pouca importância à triagem auditiva e ao seguimento do processo de diagnóstico, justificando a ausência por esquecimento e/ou perda do horário e até mesmo disseram ter testado a audição do bebê em casa. Com isto, a autora enfatiza a necessidade da elaboração de protocolos específicos de intervenção, nos quais as mães devem ser orientadas sobre a importância da audição e da detecção precoce da deficiência auditiva. Devem ser, também, sensibilizadas sobre a importância do acompanhamento para detecção de alterações auditivas que possam já existir ou surgir no transcorrer do desenvolvimento do bebê, a fim de reduzir comprometimentos futuros mais graves.

Com o intuito de pesquisar o nível de preocupação das mães frente ao resultado positivo do teste, WEICHBOLD; WELZL-MULLER ${ }^{41}, 2001$ realizaram um estudo no período de um ano, com 128 mães cujos recém-nascidos não passaram ou passaram na TANU. Esse estudo foi realizado em duas situações diferentes, sendo elas: reações imediatas das mães após o resultado positivo no primeiro teste; preocupação materna ao esperar a avaliação auditiva do bebê, depois que a mesma também não passou no reteste. As mães da primeira situação responderam três questões e as da segunda situação, duas questões referentes ao nível de preocupação quanto ao resultado do teste auditivo. Na primeira situação, das 85 mães questionadas, 34 (40\%) não souberam do resultado, das que souberam, $86 \%$ relataram que não ficaram preocupadas ou ficaram um pouco preocupadas e $14 \%$ informaram que ficaram muito preocupadas com o resultado. $\mathrm{Na}$ segunda situação, dentre as 43 mães cujos recém-nascidos não 
passaram na triagem, $42 \%$ relataram não terem ficado preocupadas, $37 \%$ informaram que ficaram um pouco preocupadas e $21 \%$ ficaram muito preocupadas.

Segundo os autores, esse estudo contradiz a conclusão de outras pesquisas sobre o nível de preocupação materna após o teste positivo da TANU, o que pode ter ocorrido devido ao número pequeno de participantes. A não preocupação das mães quanto ao resultado do teste auditivo pode ser, na realidade, desfavorável à TANU, ocasionando a perda desses bebês para o retorno ao diagnóstico audiológico. Nessa medida, parece ser necessário diminuir os resultados falso-positivos e realizar mais estudos sobre a ansiedade dos pais frente à triagem auditiva, visando encontrar estratégias de orientação que despertem a responsabilidade deles quanto à audição da criança, evitando um nível elevado de preocupação e tornando-os confiantes para retornarem ao diagnóstico audiológico.

Em uma revisão crítica de literatura, YOUNG; ANDREWS ${ }^{45}, 2001$, relataram as reações comuns dos pais que participam da TANU, em especial no que se refere ao processo e ao resultado. Os autores também discutiram os dois métodos utilizados para o cálculo da taxa de falso-positivo. São eles: cálculo da porcentagem de bebês que não passam no primeiro teste e, ao retestar, apresentam audição normal; cálculo da porcentagem de bebês que não passam no primeiro teste e no reteste e, ao realizar a bateria de exames complementares para confirmar o diagnóstico, apresentam audição normal. No primeiro método, a taxa de falso-positivo apresenta-se alta, geralmente acima de 90\%; no segundo, a taxa encontra-se em torno de 3\%. De acordo com os autores, se o segundo método for considerado o mais correto, pensando na eficiência de um programa de triagem, pouca atenção será dada ao sofrimento da família gerado pelo resultado de não passa no primeiro teste.

Para identificar e comparar a prevalência e o grau de preocupação e o conhecimento das mães a respeito da triagem auditiva neonatal, durante o teste e o reteste, VORH; LETOUNEAU; MCDERMOTT ${ }^{37}$, 2001, aplicaram o Stress Questionnarie em Rhode Island Hearing Screen Program, no período de junho/1997 a outubro/1997 e de julho/1999 a agosto/1999. Participaram do estudo 307 mães durante o teste e 40 no reteste. Os resultados obtidos mostraram que, comparada ao teste, a preocupação materna foi significativamente maior no reteste. Do total de mães, $20 \%$ com nível escolar menor, $11 \%$ com colegial incompleto e $4 \%$ com graduação referiram 
preocupação frente à triagem. E, ainda, $18 \%$ de mães com apenas um filho apresentaram nível elevado de preocupação comparado com $10 \%$ de mães com mais de um filho. Os autores concluíram que a minimização do falso-positivo e a educação das mães sobre a triagem auditiva são indicadas para diminuir o grau desnecessário de preocupação.

Em um artigo de revisão, PICTON; $\mathrm{HYDE}^{30}$, 2004, relataram que a ansiedade familiar durante o processo causa dano, em potencial, para os programas de TANU. Porém, segundo as autoras, apesar das reações encontradas nas famílias participantes desses programas, existe a aceitação desse procedimento de forma positiva.

Também com o objetivo de avaliar a ansiedade, a preocupação e o conhecimento materno referente à audição dos bebês, CROCKETT et al. ${ }^{11}$, 2006, aplicaram um questionário em quatro grupos de mães, três semanas após a triagem. $\mathrm{O}$ primeiro grupo foi composto de mães cujos bebês tiveram respostas claras no teste e reteste da triagem (número de mães $=103$ ); o segundo, de mães cujos bebês tiveram respostas claras no segundo reteste da triagem (número de mães $=81$ ); o terceiro, de mães cujos bebês não tiveram respostas claras em uma orelha no segundo reteste da triagem e foram encaminhados para o diagnóstico audiológico (número de mães $=105$ ); e o quarto, de mães cujos bebês não tiveram respostas claras em uma e/ou outra orelha no terceiro reteste auditivo e foram encaminhados para o diagnóstico audiológico (número de mães $=55$ ). Os autores constataram, então, que houve uma tendência significativa de aumento da ansiedade materna conforme eram indicados mais testes auditivos e que o conhecimento sobre a triagem auditiva não diminuiu significativamente esse sentimento. Assim, compreender o significado da importância do retorno para o diagnóstico audiológico depois da triagem pode evitar, apenas, alguma ansiedade materna associada ao acompanhamento audiológico. 


\section{2 - Impacto negativo da triagem auditiva na relação pais-bebê}

Como têm demonstrado os estudos mais recentes desenvolvidos na área, para que a perda auditiva possa ser identificada precocemente, é imprescindível observar o impacto negativo do processo diagnóstico na relação pais-criança.

No intuito de investigar a diferença no nível de estresse dos familiares de acordo com a necessidade ou não do reteste, STUART; MORETZ; YANG ${ }^{36}, 2000$, realizaram um estudo antes da alta hospitalar com mães de recém-nascidos a termo (38 e 42 semanas gestacional), normais fisicamente e neurologicamente. As participantes foram divididas em dois grupos: 20 mães de recém-nascidos que passaram na triagem e 20 mães de recém-nascidos que não passaram na triagem. A triagem auditiva foi realizada por meio do PEATE nas primeiras 24 horas e todos os familiares dos bebês que apresentaram necessidade de reteste foram informados sobre o resultado por um audiologista, antes da alta. O reteste foi realizado aproximadamente após um mês da alta hospitalar.

O instrumento de investigação utilizado foi o PSI (Índice do Estresse dos Pais - Abidin, 1995), aplicado por meio de uma entrevista pelo telefone, com duração de 20 a 30 minutos, antes da realização do reteste. Os resultados demonstraram que os dois grupos de participantes apresentaram níveis equivalentes de estresse, sendo que uma segunda conclusão foi de que as mães dos bebês que não passaram no primeiro teste não perceberam a necessidade do reteste e, portanto, não sofreram com essa possibilidade. Apesar de não haver nenhum dado empírico, os autores acreditam que, para minimizar a ansiedade dos pais, é importante ter cuidado no uso das palavras no momento de salientar a necessidade do reteste, além de sugerirem mais estudos para investigar o tema.

Também PIPP-SIEGEL; SEDEY; YOSHINAGA-ITANO ${ }^{31}, \quad 2002$, examinaram o estresse familiar em 184 mães de crianças deficientes auditivas. Os níveis de estresse foram medidos em três subescalas, usando o PSI / SF (Índice de Stress Familiar / Forma Reduzida). Esse estudo demonstrou que não há significância do grau de perda auditiva em relação à interação pais-bebê. No entanto, o nível de estresse 
aumentou quando os bebês, além da inabilidade auditiva, apresentaram o desenvolvimento de fala mais atrasado, ocasionando alterações na relação pais-bebê.

Segundo os autores, os resultados desse estudo são encorajadores em relação aos serviços de intervenção precoce, visto que algumas famílias exibiram alto nível de estresse, devido às características apresentadas pelos bebês com perda auditiva e à falta de conhecimento sobre o assunto.

Em estudo retrospectivo, POULAKIS; BARKER; WAKE ${ }^{32}, 2003$, investigaram as emoções relatadas pelos pais frente aos resultados falso-positivos, aproximadamente seis meses após o diagnóstico audiológico de seus bebês, que não revelou deficiência de audição. O estudo foi realizado em dois grupos, assim compostos: 137 bebês com presença de indicador de risco que realizaram triagem e 148 que realizaram testes comportamentais entre sete e nove meses de idade. Os autores constataram que os pais dos bebês estavam muito cientes do impacto que a perda auditiva pode causar na relação familiar e que relataram um sentimento de alívio após o diagnóstico audiológico e o fim das emoções negativas. No entanto, uma pequena porcentagem, total de $19 \%$ de ambos os grupos, referiu ter ficado preocupada em relação à audição de seu bebê, mesmo após o resultado de normalidade.

Para os autores, a equipe de profissionais envolvidas com o programa de TANU deve estar ciente das prováveis emoções experimentadas pelos pais cujos bebês não passam na primeira testagem. Além disso, ficou evidente nesse estudo que tais emoções não são aliviadas imediatamente e/ou completamente após o diagnóstico audiológico com resultado normal.

De fato, como também constatou GRACEY ${ }^{15}$, 2003, a inserção da TANU na rotina do recém-nascido e o conhecimento dessa prática por parte dos pais causam ansiedade. A duração desse sentimento tem sido citada como um risco para o relacionamento pais-bebê, especialmente diante da possibilidade de resultado falsopositivo.

Diante disso, LUTERMAN; KURTZER-WHITE ${ }^{23}$, 2003, afirmam que, antes da TANU, os pais tinham tempo para desenvolver suas próprias suspeitas por meio da interação e observação do seu bebê. Mas, com a inserção desse procedimento na rotina hospitalar, ocorre o contrário: eles recebem a notícia de que o seu bebê pode 
ter alguma deficiência de audição em um momento vulnerável na vida da família, quando a mãe ainda está se recuperando do parto, e os pais estão buscando suas identidades frente ao novo papel que irão desempenhar na estrutura familiar. As emoções estão focalizadas, então, no estabelecimento do vínculo pais-bebê, que acaba sendo afetado pela ansiedade, pois tem início uma bateria de testes auditivos para a confirmação ou não da primeira suspeita. Então, após o diagnóstico, muitas vezes os pais precisam tomar decisões diante do novo problema, do desconhecido e da falta de orientação sobre suas dúvidas, o que geralmente desencadeia raiva tanto do resultado final como do próprio profissional que participou do processo. Diante disso, os autores referem que é justamente esse profissional que pode auxiliar a família a superar esse período tão conturbado.

CROCKETT et al. ${ }^{10}$, 2005 compararam o impacto na relação mãe-bebê da ansiedade materna e a satisfação com o acompanhamento auditivo realizado por meio de dois procedimentos diagnósticos: TANU e teste comportamental feito pelos agentes de saúde (HVDT). Participaram do estudo quatro grupos de mães, sendo: 27 de bebês que receberam um resultado satisfatório no HVDT; 21 de bebês reconvocados após esse teste; 26 de bebês que receberam um resultado satisfatório na TANU e 16 de bebês reconvocados após essa triagem. Foram então aplicados questionários que avaliavam a ansiedade materna, a preocupação, o conhecimento sobre a audição dos bebês, a satisfação e as atitudes com relação ao teste de triagem. Esses questionários foram respondidos pelas mães em dois momentos: três semanas após a realização dos exames e seis meses depois.

Os autores constaram, então, que não houve diferença significativa entre os dois testes. As mães cujos bebês receberam um resultado satisfatório na TANU estavam significativamente mais satisfeitas, independente do resultado recebido, o mesmo ocorrendo com as mães cujos bebês receberam um resultado satisfatório no HVDT. Os autores concluíram que o teste de triagem auditiva neonatal não tem um impacto emocional negativo maior do que o teste comportamental realizado pelos agentes de saúde. 


\section{3 - Possíveis caminhos para acolher os familiares durante o processo de triagem auditiva}

O sucesso dos programas de saúde auditiva depende da inter-relação de vários fatores. Segundo VOHR; MOORE; TUCKER ${ }^{38}$, 2002, esses fatores dizem respeito: ao apoio e à política pública para pesquisa e monitoramento; a um sistema de monitoramento efetivo de acompanhamento; à educação continuada dos profissionais envolvidos em todos os níveis de atenção à saúde; ao envolvimento dos programas de saúde da família; à existência de centros de excelência para diagnóstico e intervenção precoce; ao uso de protocolos padronizados e validados cientificamente e ao gerenciamento de dados em nível federal, estadual e municipal.

Nessa perspectiva, DesGEORGES ${ }^{13}, 2003$, relata que é necessário que os profissionais dos programas de TANU compreendam e aprendam com as experiências das famílias a fim de melhorar o processo de diagnóstico audiológico. Nesse estudo, o autor identificou, por meio de relatos dos pais, as experiências por eles vivenciadas eles falaram sobre os profissionais e sobre o que deles esperavam, para que, juntos, pudessem alcançar o principal objetivo, qual seja, o desenvolvimento dos bebês diagnosticadas como deficientes auditivas. De acordo com a autora, muitos pais perguntam: "O que esperar do futuro do meu filho que é surdo ou deficiente auditivo?". A resposta a essa pergunta deve lhes dar esperança, para que enfrentem a realidade da identificação da perda auditiva, tomando as numerosas decisões necessárias, tais como o tipo de amplificação a ser usada, a habilitação da criança para o desenvolvimento de linguagem e fala.

A participação efetiva e colaborativa dos pais junto ao programa de detecção e intervenção precoce resulta, pois, em mudanças significativas no sentido de cuidar, informar e dar suporte às famílias, o que certamente aumenta a eficácia do procedimento diagnóstico.

Com a TANU tornando-se uma prática rotineira, compreender o seu impacto na ansiedade e vulnerabilidade da família é importante para instruí-la. Também GRACEY ${ }^{15}$, 2003, afirma que a ansiedade tem um efeito adverso no relacionamento pais-bebê, constituindo-se, portanto, em um dos fatores de risco relacionados à triagem 
auditiva neonatal universal e ao resultado do teste falso-positivo. Em seu estudo, de 20 a $50 \%$ das mães pesquisadas imediatamente depois de seus bebês não passarem nos testes audiológicos relataram seus sentimentos a respeito da TANU, tais como: raiva, confusão, depressão, frustração, choque e tristeza.

A autora refere que a ansiedade e a preocupação quanto à TANU podem ser reduzidas significativamente com estratégias específicas, tais como: diminuição dos resultados falso-positivos; educação dos pais antes, durante e após a conclusão da triagem auditiva; fornecimento de materiais escritos com os resultados dos testes e informações e, principalmente, disponibilidade para ouvir e responder perguntas de interesse, assegurando a instrução. Por fim, é necessário reforçar a importância da continuação do reteste e do diagnóstico, reeducando os pais para o desenvolvimento auditivo, linguagem e fala do seu bebê.

No caso, $\mathrm{BAROCH}^{5}, 2003$, ressalta que a TANU está transformando rapidamente o padrão do cuidado hospitalar, pois o objetivo é que seja realizada em todos os bebês até o ano de 2010, assegurando a continuação das avaliações audiológicas até os três meses, e fornecendo a intervenção precoce até os seis meses de idade. Nessa medida, os programas implementados na última década do século passado estão começando a relatar dados que serão úteis aos estados que estão começando a triagem. $\mathrm{O}$ autor revê tendências recentes, sugere protocolos apropriados de triagem e identificam áreas para a melhoria da TANU, entendida como somente a primeira etapa no cuidado de um bebê com perda auditiva. Os programas necessitam assegurar-se, pois, de que as famílias compreendam a necessidade da continuação do diagnóstico audiológico sem criar estresse impróprio. A transição para a intervenção precoce deve ser coesa, realizada por meio de uma equipe de profissionais da saúde capazes de fornecer médico, fonoaudiólogo e especialistas educacionais, visando o desenvolvimento do bebê, assim como a sustentação emocional da família.

Em síntese, o autor indica os seguintes fatores a serem considerados na efetivação dos programas de triagem: (1) os programas de triagem podem ter custobenefício com taxas baixas de orientação; (2) o estresse maternal não é necessariamente um subproduto das triagens que terminam na orientação; e (3) os resultados do desenvolvimento dos bebês com perda auditiva obtidos em hospitais públicos que realizam a triagem estão incentivando os hospitais particulares. Por fim, as áreas para a 
melhoria incluem: (1) conformidade na continuação do teste e (2) o estabelecimento de uma equipe multidisciplinar coesa para acompanhar o bebê e fornecer a sustentação à família.

Tendo como objetivo determinar se era desejável ou não o serviço de triagem auditiva em um hospital maternidade de Hong Kong, em que período e por que, NG et al. $^{27}$, 2004, selecionaram, aleatoriamente, 364 mães de crianças inseridas no programa, as quais foram bem informadas sobre o processo e as razões da triagem, sendo então aplicado um questionário contendo cinco questões. Para a testagem dos recém-nascidos, os autores utilizaram Emissões Otoacústicas Auditivas por produto de distorção (EOADP), sendo que a amostra totalizou 1064, avaliados entre maio e outubro de 1999. Foi adotado um protocolo de triagem auditiva que utilizava EOADP em três etapas $\left(1^{\circ}-4^{\circ}, 5^{\circ}-14^{\circ}\right.$ e $21^{\circ}-30^{\circ}$ dias após o nascimento), independentemente do resultado do teste. Os resultados mostraram que 3,5\% dessas crianças passaram pelo diagnóstico audiológico, incluindo as que apresentaram suspeita de perda auditiva unilateral, como também suspeita de perda auditiva bilateral.

Segundo os autores, o momento mais apropriado para a realização da triagem auditiva seria em torno do $5^{\circ}$ ao $14^{\circ}$ dia após o nascimento, pois nesse período houve um menor índice de falso-positivo. Além disso, ficou comprovada a eficácia da implementação da TANU usando a EAODP, sendo sugerido o retorno para o reteste entre o $21^{\circ}$ dia ao $30^{\circ}$ dia após o nascimento. Quanto ao questionário, 91,35\% das mães relataram que a triagem auditiva neonatal é desejável e $81,70 \%$ referiram preferir a triagem dentro dos primeiros dias de vida do recém-nascido, antes da alta hospitalar ou no retorno para o reteste. Ou seja: as mães acreditam no benefício da triagem auditiva neonatal para os seus bebês. Os autores sugerem, ainda, que outros estudos sejam realizados a fim de se determinar um protocolo de triagem auditiva neonatal ideal. Esses estudos devem ter como objetivo: o custo da triagem, assim como o custo do equipamento, dos materiais descartáveis, dos profissionais, da administração, e dos testes de continuação; além de verificar a eficácia de outras ferramentas e protocolos dos programas de triagem auditiva neonatal e a ansiedade dos pais causada por resultados falso-positivos.

Para analisar a relevância da triagem auditiva neonatal realizada por meio do potencial evocado, RUSS et al. ${ }^{34}$, 2004, aplicaram um questionário a pais de bebês 
deficientes auditivas usuárias de dispositivo eletrônico e que passaram pela triagem. Do total de participantes, $61 \%$ revelaram experiências emocionais frente à TANU tais como: negação, choque, frustração em relação ao atraso do diagnóstico, confusão para entender sobre a audição, dificuldades em entender o dispositivo eletrônico, dificuldades enfrentadas pela criança na inclusão social. Os autores concluíram que os pais necessitam de uma maior sustentação durante a triagem e o diagnóstico e que os profissionais envolvidos no processo necessitam de treinamento para aprenderem se comunicar, adequadamente, com os familiares dos bebês avaliados.

Também STOOL ${ }^{35}, 2004$, ressalta que, em primeiro lugar, é necessário informar aos pais sobre os resultados dos testes de maneira completa, o mais rápido possível, a fim de garantir o adequado encaminhamento.

Segundo a Política Nacional de Atenção à Saúde Auditiva (MINISTÉRIO DA SAÚDE $\left.{ }^{25}, 2004\right)$, um dos objetivos é desenvolver processos e métodos de coleta de dados mais efetivos, que visem à disseminação de informações e ao aprimoramento dessa gestão.

Seguindo essa mesma perspectiva de investigação, RIBEIRO ${ }^{33}$, 2005, realizou um estudo a partir do relato retrospectivo das experiências vivenciadas por três pais de bebês que participaram de um programa de triagem auditiva neonatal. Os participantes foram questionados se passaram por momentos difíceis e se viveram situações de sofrimento e angústia no período da realização da triagem auditiva até a conclusão do diagnóstico. $\mathrm{Na}$ análise das entrevistas, foram levantados vários temas sobre a vivência dos pais, tais como: dúvida sobre a presença ou não da perda auditiva, papel da equipe profissional envolvida no diagnóstico, impacto da notícia positiva, sentimento de culpa, dúvidas sobre a etiologia, divisão de papéis na estrutura familiar, expectativa quanto ao futuro da criança, entre outros. A autora concluiu, então, que quando a suspeita da deficiência auditiva no bebê ocorre após o resultado de não passa, os pais começam a vivenciar um período de muita ansiedade, pois o bebê passa a realizar uma bateria de exames auditivos para a confirmação do diagnóstico. Essa vivência, acrescida da suspeita da deficiência auditiva, causa dúvidas, e é nesse momento que o profissional envolvido no processo pode e deve auxiliar a família a superar esse período tão conturbado. 
Diante dessa realidade, a autora refere que os protocolos da TANU, embora incluam aspectos ligados à sensibilidade e à especificidade do procedimento, não abordam diretamente o momento vivido pelos pais e sua relação com as várias etapas do processo, desde a identificação do problema até a intervenção. E sugere que, em um programa de saúde auditiva, todas as etapas precisam estar bem definidas e articuladas entre si, garantindo que, ao não passar na triagem auditiva, a criança e os pais tenham acesso imediato às demais etapas do processo até a conclusão do diagnóstico audiológico e, se necessário, iniciem a intervenção fonoaudiológica o mais rápido possível, o que pode ocorrer com a inclusão em um programa de acompanhamento.

Também com o intuito de avaliar a importância do suporte aos pais nos programas de triagem auditiva neonatal, $\mathrm{HYDE}^{18}, 2005$, abordou em seu artigo aspectos como: métodos de triagem, avaliação e intervenção fonoaudiológica, resultados dos programas e papel crucial dos profissionais. A autora identificou estudos sistemáticos baseados em evidência de serviços apropriados e praticáveis de triagem auditiva neonatal universal que proporcionam benefício para muitos bebês e famílias, sendo que o suporte a estas é muito importante e positivo durante todo o processo do diagnóstico à confirmação da perda auditiva e intervenção. Muitos pais querem obter informações sobre os procedimentos realizados, os resultados dos testes, para, assim, poderem decidir qual a melhor opção de tratamento e otimizar o desenvolvimento auditivo e de comunicação do seu filho.

Segundo a autora, na triagem e nas etapas diagnósticas, o objetivo é minimizar a ansiedade dos familiares com relação aos procedimentos dos programas. É importante que o significado real do resultado seja corretamente explicado e compreendido na consulta de triagem. A informação a respeito da triagem auditiva pode ser iniciada pelos folhetos e por vídeos, disponíveis antes e depois da alta hospitalar; pode, ainda, ser reforçada por profissionais capacitados, ou mesmo pelo médico do bebê. É importante que este esteja junto aos profissionais do programa, para reforçar as informações dadas, enfatizando a importância do comparecimento para o diagnóstico e intervenções, quando necessário. Para muitos programas, mesmos aqueles de elevada qualidade, o abandono entre as fases do processo é uma ameaça significativa.

Tendo como objetivo compreender o impacto da prática da triagem auditiva neonatal, para refletir numa metodologia estruturada que permita a construção do 
conhecimento desses pais e procure compreendê-los dentro do contexto do programa, YOUNG; TARTTERSALL ${ }^{46}, 2005$, analisaram artigos que abordavam os objetivos, as justificativas e os benefícios da triagem auditiva neonatal. Em alguns, eram analisados os níveis de ansiedade materna, associados tanto à triagem auditiva quanto à satisfação do processo, sendo que a maioria empregou entrevistas estruturadas realizadas com a família. Os autores sugerem mais investigações para padronizar o tipo de perguntas que devemos fazer aos pais, para assim conseguirmos dados epidemiológicos do suporte familiar dentro do contexto da TANU.

Atualmente, vários estudiosos estão preocupados com os materiais sobre a triagem auditiva fornecidos à família. ARNOLD et al. ${ }^{2}, 2006$, afirmam que estes devem ser criteriosamente revisados para que se tornem de fácil leitura, manipulação e compreensão, tendo-se cuidado com a disposição das informações, com as ilustrações, a mensagem e a honestidade cultural, ou seja, a informação deve ser veiculada conforme a cultura familiar, a idade, as etnias e experiências prévias.

Os mesmos autores ${ }^{3}, 2006$ b, estudaram como identificar o melhor momento para orientar os pais a respeito da triagem auditiva neonatal e do diagnóstico audiológico, e concluíram que isso deve ser feito antes do nascimento. No entanto, há necessidade de desenvolver materiais educativos de fácil manipulação por parte dos familiares.

De acordo com a literatura pesquisada, podemos observar que, no geral, as preocupações dos autores têm sido as mesmas: como viabilizar a participação dos familiares nos programas de triagem, de modo que possam contribuir para a agilização do processo diagnóstico e receber orientações adequadas sobre o futuro de suas crianças, especialmente daquelas com deficiência auditiva. Afinal, é primordialmente no contexto familiar que são criadas as condições para o favorecimento do desenvolvimento da linguagem, cognitivo e social. 

3 - PROPOSIÇÃO 



\section{3 - PROPOSIÇÃO}

O objetivo do presente estudo foi identificar o grau de preocupação dos familiares com relação à TANU e o quanto conhecem desse procedimento e sobre a audição do bebê. Torna-se possível, assim, identificar estratégias de acolhimento das necessidades da família durante todo processo de diagnóstico audiológico, bem como contribuir para o planejamento de ações fonoaudiológicas que viabilizem orientações mais eficazes. 

4 - MATERIAL E MÉTODO 



\section{4 - MATERIAL E MÉTODO}

\section{1 - Local}

O presente estudo foi desenvolvido na Clínica de Audiologia Infantil do Departamento de Fonoaudiologia da Faculdade de Odontologia de Bauru da Universidade de São Paulo, e está inserido no Projeto "Modelo de Saúde Auditiva no Recém-nascido" - Edital Políticas Públicas, FAPESP, processo n 2003/06415-6. A validação e o protocolo foram realizados pelo Comitê de Ética da Faculdade de Odontologia de Bauru da Universidade de São Paulo, sob o n 118/2005.

A metodologia do projeto inclui o Programa de Triagem Auditiva Neonatal Universal realizado na Maternidade Santa Isabel - Bauru/SP, único hospital maternidade público que atende a cidade de Bauru e região, com média de 300 recém-nascidos/mês.

Após a triagem auditiva, os recém-nascidos encaminhados para diagnóstico são atendidos na Clínica de Audiologia Infantil do Curso de Fonoaudiologia da Faculdade de Odontologia de Bauru-USP.

\section{2 - Casuística}

O estudo foi realizado no período de 06 de março a 28 de junho de 2006. Das 42 famílias - mãe e/ou pai e bebê - inicialmente selecionadas, restaram 38 de acordo com os seguintes critérios: 


\section{Critérios de inclusão:}

Foram incluídas todas as famílias cujos bebês não haviam passado no teste e reteste da TANU realizados na maternidade, haviam sido encaminhados para diagnóstico audiológico e ainda não o haviam iniciado na ocasião do estudo.

\section{Critérios de exclusão:}

Foram excluídas as famílias:

- que se recusaram a responder ao questionário, no caso, duas mães;

- aquelas cujos bebês apenas haviam realizado o teste da triagem auditiva e não o reteste na maternidade - apenas uma família;

- aquelas cujos bebês já tivessem dado início ao processo diagnóstico na Clínica de Audiologia Infantil do Curso de Fonoaudiologia FOB-USP- também neste caso, uma família.

Todas as respondentes foram às mães, pois, quando presentes (total de cinco), os pais apenas confirmaram as respostas por elas já fornecidas.

A faixa etária materna e paterna estuda variou de:

- Materna: 16 anos, idade mínima e 40 anos a máxima;

- Paterno: 19 anos, idade mínima e 47 anos a máxima.

O número total de bebês deste estudo foi 39 , pois uma das mães deu à luz a trigêmeos, sendo que um deles não sobreviveu.

Ressaltamos que, depois de finalizada a coleta de dados, todos os bebês das 38 famílias pesquisadas deram continuidade ao processo diagnóstico na Clínica de Audiologia Infantil do Curso de Fonoaudiologia FOB-USP. 


\section{3 - Instrumento}

A construção do instrumento utilizado neste estudo resultou da adaptação, na íntegra, de dois questionários selecionados de acordo com o objetivo aqui proposto, sendo que ambos foram solicitados aos autores, via e-mail, assim como a autorização para aplicá-los no Brasil. São eles:

- O Rhode Island Hearing Screen Program Questionnarie, que foi aplicado e analisado por VOHR et al. ${ }^{37}$, 2001, a fim de identificar e comparar a prevalência e o grau de preocupação materna do Rhode Island Hearing Assesment Program (RIHAP) do Women \& Infants Hospital. Esse questionário está dividido em duas partes e sua aplicação ocorre em dois momentos. A primeira parte compreende o programa de triagem aplicado no hospital depois do teste de EOA, e a segunda parte abrange a consulta do reteste, sendo aplicada no hospital logo após o exame do reteste (Anexo1). No presente estudo, as questões de um a treze baseiam-se neste questionário (Anexo 3).

- O questionário formulado e aplicado por Hergils; Hergils ${ }^{17}, 2000$ durante a rotina hospitalar e após o teste e reteste da triagem auditiva do programa TANU da University Hospital, Linköping, Suécia. Contém cinco questões abertas referente às experiências, aos pensamentos, às opiniões e informações dos pais em relação à TANU (Anexo 2). No presente estudo, as questões quatorze a dezoito baseiam-se neste questionário (Anexo 3).

A seleção de ambos ocorreu em virtude da relevância dos temas neles abordados, tais como: gestação e suas possíveis intercorrências, peso do bebê ao nascer e outros dados referentes ao pós-nascimento. Também são abordados aspectos como escolaridade, estrutura e antecedentes familiares dos pais, assim como reflexões e expectativas destes frente ao teste, reteste e à audição do bebê. 
Visando um melhor entendimento sobre ao instrumento elaborado nesta pesquisa, foi realizada uma breve revisão de literatura (Anexo 4).

\section{4 - Validação do instrumento}

Para verificação de adequação, o instrumento foi encaminhado a três juízes fonoaudiólogos com vasta experiência e reconhecimento nacional pelo trabalho realizado na área da deficiência auditiva.

A validação do instrumento foi dada após o recebimento dos pareceres dos juízes e a inclusão das questões dezenove a vinte e três.

Foi então realizado um piloto, para averiguarmos a adequação do procedimento ao objetivo aqui proposto, a necessidade ou não de eventuais modificações no questionário bem como para estimarmos o tempo de aplicabilidade deste, que foi de, aproximadamente, 30 minutos. Em vista disto, constatamos que não haveria interferência na rotina do processo diagnóstico audiológico realizado no programa.

O questionário foi então definido como instrumento do estudo proposto e teve início a coleta de dados da dissertação.

Após o exame de qualificação, foi sugerida pela Banca Examinadora a inclusão da questão vinte e quatro como complementação do instrumento (Anexo 3).

\section{5 - Coleta e registro dos dados}

A coleta de dados ocorreu a partir do dia 06 de março, sendo concluída em 28 de junho de 2006, conforme a disponibilidade da Clínica de Audiologia Infantil do Curso de Fonoaudiologia FOB-USP.

As sessões de coleta de dados foram programadas de acordo com a disponibilidade dos participantes, na própria rotina pré-estabelecida pelo programa, e 
realizadas em uma sala cedida pela Clínica de Audiologia Infantil do Curso de Fonoaudiologia FOB-USP. Nela permaneciam o experimentador, a mãe e/ou pai e o bebê. Antes do início dos exames audiológicos, a pesquisadora lia para os pais a Carta de Informação ao Sujeito da Pesquisa e, caso concordassem, eles assinavam o Termo de Consentimento Livre e Esclarecido (Anexo 5).

O questionário foi apresentado aos pais por meio de entrevista dirigida, sendo as questões apresentadas da forma como estavam redigidas; apenas em algumas ocasiões considerou-se necessário reformulá-las oralmente para garantir a compreensão pelos participantes.

Os resultados foram registrados em folhas sulfites e gravados em um gravador Digital Voice Recorder VN-480PC-Olympus, para posterior análise.

\section{6 - Análise dos resultados}

A análise dos resultados do presente estudo foi dividida em cinco etapas:

1) Caracterização demográfica da casuística:

- População entrevistada - nível de escolaridade e dados gestacionais;

- Bebês - gênero, peso ao nascimento, presença ou ausência de indicadores de risco e faixa etária.

2) Levantamento dos dados e contabilização das questões fechadas - foi realizada a tabulação de dados para cada participante a partir da enumeração dos itens das respostas, conforme o número correspondente a cada questão.

3) Transcrição das respostas das questões abertas - todas as respostas foram transcritas, sendo o objetivo a identificação dos temas representativos. 
4) Explorações dos temas representativos - foram realizadas pela análise sistemática da transcrição do discurso, verificando-se as palavras ou frases freqüentemente mais repetidas e que apresentavam um significado importante que corroborava com o objetivo do presente estudo.

5) O tratamento dos resultados foi realizado em duas partes:

- Análise descritiva, visando caracterizar a casuística;

- Análise estatística, por meio dos seguintes procedimentos: Teste nãoparamétrico de Wilcoxon entre dois grupos pareados; Coeficiente de correlação de Spearman; Teste não paramétrico de Kruskal Wallis e Teste de Dunn para comparação individual. Para todos os testes estatísticos foi adotado o nível de significância de 5\%. 
5 - RESULTADOS 



\section{5 - RESULTADOS}

Neste capítulo são apresentados os resultados obtidos no presente estudo. Os dados correspondentes a cada questão formulada aos familiares foram organizados nos bancos de dados, contabilizados, representados por tabelas e tratados de forma descritiva e quantitativa, ambas baseadas em eixos de análise.

\section{1 - Eixos de análise}

5.1.1 - Distribuição da caracterização demográfica da casuística;

5.1.2 - Identificação e avaliação do grau de preocupação familiar a respeito da TANU;

5.1.3 - Identificação do conhecimento da família a respeito da TANU e da audição do bebê;

5.1.4 - Identificação de estratégias de orientação fonoaudiológica a partir das sugestões apresentadas pelas famílias do programa.

\subsection{1 - Distribuição da caracterização demográfica das famílias participantes}

Das 38 famílias participantes do estudo, obtivemos as variáveis que se seguem quanto à identificação.

Na Tabela 1 observamos o grau de escolaridade, 39\% das mães tinham apenas o $1^{\circ}$ grau incompleto, e $34 \%$, o $2^{\circ}$ grau completo. E quanto aos pais, $26 \%$ tinham o $1^{\circ}$ grau incompleto e $42 \%$, o $2^{\circ}$ grau completo. 
TABELA 1- Distribuição da casuística segundo o grau de escolaridade dos pais

\begin{tabular}{lcccc}
\hline Grau de escolaridade & $\mathbf{N}^{\circ}$ de mães & $\mathbf{\%}$ & $\mathbf{N}^{\circ}$ de pais & $\mathbf{\%}$ \\
\hline $1^{\circ}$ Grau Incompleto & 15 & 39 & 11 & 26 \\
$1^{\circ}$ Grau Completo & 5 & 13 & 4 & 13 \\
$2^{\circ}$ Grau Incompleto & 3 & 8 & 4 & 11 \\
$2^{\circ}$ Grau Completo & 13 & 34 & 16 & 42 \\
$3^{\circ}$ Grau Incompleto & 1 & 3 & 3 & 8 \\
$3^{\circ}$ Grau Completo & 1 & 3 & 0 & 0 \\
\hline TOTAL & $\mathbf{3 8}$ & $\mathbf{1 0 0 \%}$ & $\mathbf{3 8}$ & $\mathbf{1 0 0 \%}$ \\
\hline
\end{tabular}

A Tabela 2 apresenta a distribuição das mães segundo o número de filhos: $55 \%$ delas tinham apenas um filho.

TABELA 2 - Distribuição demográfica da casuística quanto ao número de filhos

\begin{tabular}{ccc}
\hline Número de filhos & Número de mães & \% \\
\hline 1 & 21 & 55 \\
2 & 9 & 26 \\
3 & 5 & 13 \\
4 & 1 & 3 \\
5 & 1 & 3 \\
\hline TOTAL & $\mathbf{3 8}$ & $\mathbf{1 0 0 \%}$ \\
\hline
\end{tabular}


Quanto ao tipo de parto (Tabela 3), 54\% foram cesarianos e $46 \%$, normais. No que se refere a problemas na gestação, 69\% afirmaram que não houve nenhum tipo de intercorrência, enquanto $31 \%$ referiram ter apresentado intercorrências como: rompimento precoce da bolsa, infecção urinária, descolamento da placenta, depressão, pressão alta e neoplasia mamária.

TABELA 3 - Distribuição demográfica da casuística referente aos dados gestacionais: tipo de parto e intervenção gestacional

\begin{tabular}{cccc}
\hline Variável & Detalhes & $\mathbf{N}^{\circ}$ de mães & \% \\
\hline \multirow{2}{*}{ Tipo de parto } & Cesárea & 21 & 54 \\
& Normal & 17 & 46 \\
Intercorrência & Sim & 27 & 31 \\
Gestacional & Não & 11 & 69 \\
\hline TOTAL & & $\mathbf{3 8}$ & $\mathbf{1 0 0 \%}$ \\
\hline
\end{tabular}

* Todas as mães que apresentaram intercorrências gestacionais referiram ter feito uso de medicamentos

A Tabela 4 apresenta a caracterização dos bebês. A variável sobre a idade gestacional foi de, no mínimo, 27 semanas e, no máximo, de 42 semanas, sendo a média de 38 semanas gestacionais. O peso dos bebês ao nascimento foi, em média, de $2889 \mathrm{~g}$, e a faixa etária média foi de 47 dias, no momento da coleta de dados.

TABELA 4 - Distribuição da característica da casuística referente aos bebês quanto à idade gestacional, ao peso ao nascimento e à faixa etária

\begin{tabular}{lccccc}
\hline \multicolumn{1}{c}{ Variável } & Máximo & Mínimo & Média & Mediana & $\begin{array}{c}\text { Total de } \\
\text { sujeitos }\end{array}$ \\
\hline $\begin{array}{l}\text { Idade Gestacional } \\
\text { (semanas) }\end{array}$ & 42 & 27 & 38 & 40 & $\mathbf{3 8}$ \\
Peso no nascimento & 3.985 & 935 & 2.889 & 3.085 & $\mathbf{3 9}$ \\
Faixa Etária (dias) & 371 & 21 & 81,21 & 47 & $\mathbf{3 9}$ \\
\hline
\end{tabular}

* O número total de bebês foi 39, pois uma das mães deu à luz a trigêmeos, sendo que um deles não sobreviveu 
Quanto ao gênero dos bebês, podemos observar na Tabela 5 que 67\% deles eram do gênero masculino e $33 \%$ do feminino.

TABELA 5 - Distribuição demográfica da casuística referente ao gênero dos bebês e à presença ou ausência de indicadores de risco

\begin{tabular}{ccccc}
\hline Variável & Detalhes & $\mathbf{N}^{\circ}$ de bebês & $\mathbf{\%}$ & $\begin{array}{c}\text { Total de } \\
\text { bebês }\end{array}$ \\
\hline \multirow{2}{*}{ Gênero } & Masculino & 26 & 67 & \\
& Feminino & 13 & 33 & $\mathbf{3 9}$ \\
Indicadores de & Sim & 19 & 49 & \\
Risco & Não & 20 & 51 & \\
\hline
\end{tabular}

Quanto à presença de indicadores de risco, conforme o JCIH (2000), 51\% dos bebês não os apresentaram e 49\% apresentaram um ou mais - conforme mostra a Tabela 6. Ainda nessa mesma tabela, observamos que a maioria dos bebês, $20 \%$, apresentou prematuridade como indicador de risco, seguido de $18 \%$ de antecedentes familiares com deficiência auditiva congênita e $18 \%$ usuários de UTI $\geq 5$ dias. Em menores índices, encontramos os demais indicadores de risco, conforme apresentado.

TABELA 6 - Caracterização dos indicadores de risco dos bebês

Indicadores de risco

Bebês (n=19) $\%$

Desordens Crânios-faciais

1

3

Ototoxidade Medicamentosa

2

5

Transfusão Sanguínea

2

5

Síndrome

3

8

Ventilação mecânica $\geq 10$ dias

4

Baixo Peso

5

$\mathrm{UTI} \geq 5$ dias 7

D.A. Congênita na família 7

Prematuridade 8 
A Tabela 7 apresenta os antecedentes familiares em relação à deficiência auditiva congênita, totalizando sete familiares, sendo que três são usuários de AASI e quatro não fazem uso de aparelhos, segundo relatos das mães-respondentes.

TABELA 7 - Caracterização dos antecedentes familiares deficientes auditivos congênitos da casuística

\begin{tabular}{clcc}
\hline \multirow{2}{*}{ Variável } & \multicolumn{1}{c}{ Grau de parentesco } & \multicolumn{2}{c}{ Usuário de AASI } \\
& Irmão Materno & Sim & Não \\
\hline & Tia Materna & Sim & - \\
& Mãe & - & Não \\
Deficiência Auditiva & Avó Materna & - & Não \\
Congênita & Tia Paterna & - & Não \\
& Prima Paterna $\left(1^{\circ}\right.$ Grau $)$ & Sim & - \\
& Irmão Materno $(*$ Má-formação MAE e OM $)$ & - & Não \\
\hline TOTAL & 7 & 3 & 4 \\
\hline
\end{tabular}

* Má-formação do Meato Acústico Externo e da Orelha Média 


\subsection{2 - Identificação e avaliação do grau de preocupação familiar a respeito da TANU}

A Tabela 8 apresenta os resultados quanto ao grau de preocupação entre o teste e o reteste durante a TANU. Para essa análise utilizamos o teste não paramétrico de Wilcoxon para dois grupos não pareados, inicialmente verificando a significância entre o grau de preocupação no teste e no reteste, para depois avaliarmos se esse grau aumentou, manteve-se igual ou diminuiu. Podemos observar que, das 38 mãesrespondentes, 10 disseram não ter se preocupado durante o teste, enquanto no reteste apenas quatro não mostraram preocupação. Nessa medida, houve um aumento significativo $(\mathrm{p}=0.002)$ do grau de preocupação do teste para o reteste - de preocupada (7 para 10 mães) para muito preocupada (9 para 14 mães). Apenas cinco mães (13\%) referiram ter diminuído o grau de preocupação entre o teste e o reteste, o que ocorreu em razão das informações e orientações recebidas, que, segundo elas, não deixaram dúvidas sobre o procedimento. 
TABELA 8 - Grau de preocupação materna entre o teste e o reteste durante a TANU

\begin{tabular}{|c|c|c|c|c|c|c|c|c|}
\hline & $\begin{array}{c}\text { Não } \\
\text { Preocupada }\end{array}$ & $\begin{array}{l}\text { Ligeiramente } \\
\text { Preocupada }\end{array}$ & $\begin{array}{c}\text { Um pouco } \\
\text { Preocupada }\end{array}$ & Preocupada & $\begin{array}{c}\text { Muito } \\
\text { Preocupada }\end{array}$ & Média & Mediana & $\mathbf{P}$ \\
\hline Teste & 10 & 2 & 10 & 7 & 9 & 2.13 & 2.00 & $\begin{array}{c}0.002 \\
*\end{array}$ \\
\hline Reteste & 4 & 0 & 10 & 10 & 14 & 2.81 & 3.00 & \\
\hline
\end{tabular}

* Estatisticamente significante $(p<0.05)$ 
$\mathrm{Na}$ Tabela 9 podemos observar a relação entre o grau de preocupação das participantes durante o reteste e o nível de escolaridade, o número de filhos e a presença de indicadores de risco. Para essa análise foi utilizado o Coeficiente de Correlação de Sperman, que, embora não tenha fornecido uma probabilidade estatística significante, indicou que: quanto maior o grau de escolaridade, menor o grau de preocupação no reteste; quanto maior o número de filhos, menor o grau de preocupação e quando não existe indicador de risco, menor o grau de preocupação no reteste da TANU.

TABELA 9 - Grau de preocupação das mães em relação ao nível de escolaridade, número de fillhos e indicador de risco

\begin{tabular}{|cccc}
\hline Variável & $\begin{array}{c}\text { Coeficiente de } \\
\text { Spearman }\end{array}$ & Probabilidade & $\begin{array}{c}\text { Total de } \\
\text { Mães }\end{array}$ \\
\hline Nível de Escolaridade X Grau de Preocupação & -0.155 & $0.350 \mathrm{~ns}^{*}$ & 38 \\
N$^{\circ}$ de Filhos X Grau de Preocupação & -0.297 & $0.069 \mathrm{~ns}^{*}$ & 39 \\
Indicador de Risco X Grau de Preocupação & -0.109 & $0.506 \mathrm{~ns}^{*}$ & 39 \\
\hline
\end{tabular}

*ns - Correlação estatisticamente não significante

No que se refere à questão dezenove (Tabela 10) -"se a mãe, em algum momento, pensou em não levar o bebê para o diagnóstico auditivo e por que”, os dados coletados revelaram que, dentre as 38 mães-respondentes, quatro $(11 \%)$ disseram que pensaram em não levar o bebê para o diagnóstico. Segundo essas mães, isso ocorreu devido à dificuldade em voltar ao programa, à falta de vale transporte e ao medo da confirmação do problema. Entretanto, todas retornaram ao programa por estarem preocupadas com a possibilidade de o bebê ter uma deficiência auditiva. As outras 34 mães $(89 \%)$ afirmaram que em nenhum momento pensaram em não levar o bebê para diagnóstico audiológico; destas, a maioria, 47\%, mencionou ter retornado ao programa por considerá-lo necessário. 
TABELA 10 - Dados sobre a possibilidade de, em algum momento, a família ter pensado em "Não" levar o bebê para o diagnóstico audiológico

\begin{tabular}{|c|c|c|c|c|c|}
\hline Pergunta & Respostas & $\begin{array}{c}\text { Mães } \\
(\mathbf{n}=38)\end{array}$ & $\%$ & Por quê? & $\begin{array}{l}\mathbf{N}^{\circ} \text { de } \\
\text { mães }\end{array}$ \\
\hline \multirow{4}{*}{$\begin{array}{c}\text { Em algum momento você } \\
\text { pensou em não trazer o } \\
\text { seu bebê para o } \\
\text { diagnóstico audiológico? }\end{array}$} & Sim & 4 & 11 & $\begin{array}{l}\text { Medo da confirmação de um } \\
\text { problema } \\
\text { Por achar desnecessário } \\
\text { Por dificuldade de voltar ao } \\
\text { programa } \\
\text { *Outros }\end{array}$ & $\begin{array}{l}1 \\
0 \\
2 \\
1\end{array}$ \\
\hline & \multirow[b]{3}{*}{ Não } & \multirow[b]{3}{*}{34} & & $\begin{array}{l}\text { Medo de existir um problema e } \\
\text { o bebê ficar sem tratamento } \\
\text { Por achar necessário }\end{array}$ & $\begin{array}{l}10 \\
16\end{array}$ \\
\hline & & & & Por ser gratuito & 1 \\
\hline & & & 89 & $\begin{array}{l}\text { Por achar necessário } \\
\text { Ser gratuito } \\
\text { Medo de existir um problema e } \\
\text { o bebê ficar sem tratamento } \\
\text { Por achar necessário } \\
\text { Por ser gratuito } \\
\text { Medo de existir um problema e } \\
\text { o bebê ficar sem tratamento } \\
\text { Por achar necessário }\end{array}$ & 3 \\
\hline
\end{tabular}

* Outros - apenas uma mãe disse que considerava perda de tempo voltar ao programa

\subsection{3 - Identificação do conhecimento familiar a respeito da TANU e da audição do beb̂̂}

A Tabela 11 apresenta o conhecimento materno a respeito do teste da TANU. Observamos que $50 \%$ das mães souberam da participação de seus bebês no momento da alta hospitalar; 34\%, durante a internação e $16 \%$, antes da internação hospitalar, neste caso por meio de amigas ou vizinhas cujos filhos já haviam participado do programa.

Em relação à questão: “quem informou sobre o teste?”, 37\% disseram ter sido a enfermeira da maternidade, $21 \%$, o pediatra da maternidade, $18 \%$, outras pessoas, como assistente social da maternidade, assistente social do posto de saúde da cidade em 
que reside, ou mesmo amigas e vizinhas que participaram do programa, e $11 \%$ das mães foram informadas pelas fonoaudiólogas na maternidade.

Sobre a questão: "o que a mãe esperava acontecer na triagem auditiva”, respondida por apenas 28 mães, devido à inclusão dessa pergunta apenas após a qualificação, 61\% delas esperavam que o seu bebê tivesse a audição testada, enquanto $36 \%$ disseram não saber o que esperar; apenas uma participante referiu que soube do teste depois que o seu bebê já o havia realizado no berçário.

A Tabela 12 apresenta a caracterização do conhecimento materno a respeito do reteste da TANU. Constatamos que $84 \%$ das mães esperavam que o seu bebê tivesse a audição avaliada no primeiro teste da triagem e 16\% não sabiam o que esperar no reteste. Quando questionadas se "foi dado algum resultado após o reteste", 92\% disseram que sim, relatando que tinham sido informadas sobre a importância do encaminhamento para a Clínica de Audiologia Infantil do Curso de Fonoaudiologia da FOB-USP. Segundo as mães, essa clínica foi descrita como tendo melhores aparelhos para saber se o bebê ouvia ou não, pois não tinha sido possível a finalização do teste na maternidade, devido à cera ou aguinha do parto $^{1}$ no conduto auditivo. Do total de mães-respondentes, 3\% relataram que não lhes foi fornecido nenhum tipo de orientação, apenas entregue um papel com a data e hora marcada para realizar, novamente, o teste na Clínica da USP.

Quando questionadas se sabiam quem realizou o reteste, 55\% relataram que não, 39\% afirmaram ter sido a fonoaudióloga, pois leram esta palavra no jaleco, porém, não sabiam precisar se havia sido uma estagiária, uma aluna ou profissional; e $5 \%$ relataram que foi a enfermeira.

\footnotetext{
* 1 As frases que estão entre aspas e itálico são as perguntas referentes ao instrumento da pesquisa. As frases que se encontram sem aspas e em itálico são os discursos utilizados pelas mães, que foram rigorosamente transcritos.
} 
TABELA 11 - Conhecimento materno a respeito do teste da TANU

\begin{tabular}{|c|c|c|c|}
\hline Perguntas & Detalhes & $\begin{array}{c}\text { Mães } \\
(n=38)\end{array}$ & $\%$ \\
\hline \multirow{3}{*}{$\begin{array}{l}\text { Quando soube da TANU. } \\
\text { (questão } n^{\circ} 2 \text { ) }\end{array}$} & Antes da internação hospitalar & 6 & 16 \\
\hline & Durante a internação hospitalar & 13 & 34 \\
\hline & *Depois da alta hospitalar & 19 & 50 \\
\hline \multirow{5}{*}{$\begin{array}{l}\text { Quem informou sobre a } \\
\text { TANU. } \\
\text { (questão } n^{\circ} \text { 3) }\end{array}$} & Enfermeira da maternidade & 14 & 37 \\
\hline & Pediatra da maternidade & 8 & 21 \\
\hline & Outros & 7 & 18 \\
\hline & Não souberam responder & 5 & 13 \\
\hline & Fonoaudióloga & 4 & 11 \\
\hline $\begin{array}{l}\text { O que a mãe esperava } \\
\text { acontecer na triagem }\end{array}$ & Teste Auditivo & 17 & 61 \\
\hline auditiva. & Não sabia o que esperar & 10 & 36 \\
\hline $\begin{array}{l}(\mathrm{n}=28) \\
\left(\text { questão } n^{\circ} 24\right)\end{array}$ & Outros & 1 & 3 \\
\hline A mãe ficou preocupada em & Sim & 15 & 40 \\
\hline saber se o bebê teria que & Não & 23 & 60 \\
\hline $\begin{array}{l}\text { fazer a TANU? } \\
\text { (questão } n^{\circ} 4 \text { ) }\end{array}$ & Não Lembra & 0 & 0 \\
\hline $\begin{array}{l}\text { A mãe conseguia lembrar o } \\
\text { que foi dito a ela logo após o }\end{array}$ & Sim & 35 & 92 \\
\hline $\begin{array}{l}\text { primeiro teste da triagem. } \\
\text { (questão } n^{\circ} \text { 5) }\end{array}$ & Não & 3 & 8 \\
\hline $\begin{array}{l}\text { A mãe recebeu algum } \\
\text { folheto explicativo sobre o } \\
\text { programa de triagem }\end{array}$ & $\operatorname{Sim}$ & 0 & 0 \\
\hline $\begin{array}{l}\text { auditiva. } \\
\left.\text { (questão } n^{\circ} 7\right)\end{array}$ & Não & 38 & 100 \\
\hline
\end{tabular}

*Momento da alta hospitalar 
TABELA 12 - Caracterização do conhecimento materno frente ao reteste da TANU

\begin{tabular}{|c|c|c|c|}
\hline Perguntas & Detalhes & $\begin{array}{c}\text { Mães } \\
(\mathrm{n}=38)\end{array}$ & $\%$ \\
\hline \multirow{3}{*}{$\begin{array}{l}\text { O que você esperava acontecer no } \\
\text { reteste? }\end{array}$} & Teste Auditivo & 32 & 84 \\
\hline & Não sabia o que esperar & 6 & 16 \\
\hline & Outros & 0 & 0 \\
\hline \multirow{4}{*}{$\begin{array}{l}\text { Foi dado a você algum resultado após } \\
\text { o reteste? }\end{array}$} & Sim & 35 & 92 \\
\hline & Não & 3 & 8 \\
\hline & Parcial & 0 & 0 \\
\hline & Não lembro & 0 & 0 \\
\hline \multirow{4}{*}{ Você sabe quem fez o reteste? } & Técnico em triagem & 0 & 0 \\
\hline & Enfermeira & 2 & 5 \\
\hline & Fonoaudióloga & 15 & 39 \\
\hline & Não sei & 21 & 55 \\
\hline
\end{tabular}

A Tabela 13 apresenta a relação entre a pergunta "Quando a mãe soube da TANU” e o grau de preocupação materna frente ao teste da triagem auditiva. Foi realizado o teste não paramétrico de Kruskall Wallis, que apresentou significância estatística $(H=10.73 ; p=0.005)$, e o teste de Dunn para comparações individuais, com nível de significância igual a 0.05 . Verificamos presença de significância na comparação entre "A x C", ou seja, o grau de preocupação frente ao teste mostrou-se maior no caso das mães que souberam da TANU depois da alta em vez de antes da internação hospitalar.

Entretanto, quando aplicado à análise estatística do teste não paramétrico de Kruskall Wallis de comparação para dois grupos independentes, diagnóstico audiológico e grau de preocupação materna no teste, não houve presença de significância estatística $(\mathrm{H}=2.91 ; \mathrm{p}=0.2333)$. 
TABELA 13 - Grau de preocupação das mães em relação ao momento em que souberam da triagem auditiva

\begin{tabular}{cccc}
\hline Comparação & Diferença & Valor crítico & Interpretação \\
\hline A x B & -6.1923076 & 13.1304106 & Não significante \\
A x C & -14.763157 & 12.4585181 & Significante \\
B x C & -8.5708502 & 9.57580566 & Não Significante \\
\hline
\end{tabular}

* A letra "A" refere-se a "antes da internação hospitalar"; a letra "B", "durante a internação hospitalar" e a letra "C", "depois da alta hospitalar".

A Tabela 14 apresenta o conhecimento das mães a respeito das perguntas sobre a audição do bebê: $87 \%$ declararam ter percebido que o seu bebê não ouvia, enquanto $13 \%$ relataram dúvidas quanto a essa aptidão; 100\% afirmaram ser importante o bebê ouvir, porém, 14 não souberam justificar por que, enquanto as demais disseram: ouvir é importante; não ouvir é ruim; ouvir é importante para o bebê poder me ouvir; o sonho da mãe é que o bebê seja perfeito, entre outras. Com relação à pergunta: "Você já conseguiu perceber se o seu bebê ouve? Exemplifique”, a maioria respondeu afirmativamente, exemplificando com as seguintes situações: reage a sons fortes, olha quando ela fala, assusta com barulho alto, procura o barulho ou a voz com os olhos, assusta com gritos, assusta e pula com barulho muito alto. Apenas três mães afirmaram não ter conseguido perceber reações auditivas em seus bebês, pois não sabiam o que observar. 
TABELA 14 - Conhecimento materno sobre a importância da audição do bebê e percepção quanto à audição do seu bebê

\begin{tabular}{|c|c|c|c|c|c|}
\hline Perguntas & Respostas & $\begin{array}{c}\text { Mães } \\
(\mathbf{n}=38)\end{array}$ & $\%$ & $\begin{array}{c}\text { Detalhes das respostas dadas pelas } \\
\text { mães }\end{array}$ & $\begin{array}{l}\mathrm{N}^{\circ} \text { de } \\
\text { mães }\end{array}$ \\
\hline $\begin{array}{l}\text { Você acha que o } \\
\text { seu bebê ouve } \\
\text { bem? }\end{array}$ & NÃO & 33 & 87 & $\begin{array}{l}\text { * Quando a mãe não afirmou que seu } \\
\text { bebê ouvia ou mesmo relatou dúvidas } \\
\text { quanto a isso, consideramos a } \\
\text { resposta como “não". }\end{array}$ & 38 \\
\hline $\begin{array}{l}\text { Você acha } \\
\text { importante o bebê } \\
\text { ouvir? Por quê? }\end{array}$ & SIM & 38 & 100 & $\begin{array}{l}\text { Não sei } \\
\text { Ouvir é importante } \\
\text { Para o bebê poder me ouvir } \\
\text { O sonho da mãe é que o bebê seja } \\
\text { perfeito } \\
\text { Não ouvir é ruim } \\
\text { Para aprender a falar } \\
\text { É o órgão do sentido mais importante } \\
\text { Para brincar } \\
\text { Para ele se movimentar }\end{array}$ & $\begin{array}{l}14 \\
5 \\
5\end{array}$ \\
\hline \multirow[t]{2}{*}{$\begin{array}{l}\text { Você já conseguiu } \\
\text { perceber se o seu } \\
\text { bebê ouve? } \\
\text { Exemplifique. }\end{array}$} & SIM & 35 & 92 & $\begin{array}{l}\text { Reage com sons fortes } \\
\text { Reage com sons altos e olha quando } \\
\text { fala } \\
\text { Assusta com barulho alto } \\
\text { Procura o barulho ou a voz com os } \\
\text { olhos } \\
\text { Assusta com gritos }\end{array}$ & 10 \\
\hline & NÃO & 3 & 8 & $\begin{array}{l}\text { Não consegui perceber se o bebê } \\
\text { Não sei o que eu tenho que perceber. }\end{array}$ & 3 \\
\hline
\end{tabular}

* Manteve-se o tipo de discurso utilizado pelas mães.

Quanto aos 39 bebês avaliados, o resultado do diagnóstico audiológico foi: 18 apresentaram resultados dentro do padrão de normalidade em todos os exames específicos e receberam alta; 19 encontram-se em acompanhamento devido à presença 
de um ou mais indicadores de risco de deficiência auditiva e 2 foram diagnosticados com deficiência auditiva - um apresentou perda auditiva neurossensorial bilateral severa a profunda, e o outro perda auditiva neurossensorial profunda bilateral.

Todas as mães participantes do programa receberam orientações quanto ao resultado audiológico e sobre o desenvolvimento auditivo, de linguagem e fala (Anexo $6)$.

Os bebês que foram diagnosticados com deficiência auditiva na ocasião deste estudo encontravam-se, conforme o protocolo, dentro do contexto do programa de atenção à saúde auditiva, em processo terapêutico, na Clínica de Audiologia Infantil do Curso de Fonoaudiologia da FOB-USP.

\subsection{4 - Identificação de estratégias de orientação fonoaudiológica a partir das sugestões apresentadas pelas famílias do programa}

As respostas das mães para a questão: "Qual foi sua experiência a respeito da triagem auditiva?" foram as seguintes: 63\% afirmaram ter sido uma experiência satisfatória, justificando que, por meio da TANU, poderiam saber se o seu bebê ouvia; $37 \%$ relataram ter ficado insatisfeitas e preocupadas devido à falta de informações e à demora para saber o resultado final.

Em relação à questão: “Com a triagem auditiva surgiram algumas questões ou pensamentos?”, 55\% das mães relataram que, nesse período, alguns pensamentos surgiram como: achei que o meu bebê poderia ser surdo; fiquei com medo e muito preocupada; quero saber se o meu filho ouve; comecei a prestar mais atenção na audição do meu bebê; achei que ele é surdo e vai ter que usar aparelho; gostaria de saber se isso acontece com outras crianças. No entanto, $45 \%$ das mães não quiseram argumentar sobre a resposta.

Sobre a questão: "Você é favorável ou não a este teste? Por favor, explique”, $100 \%$ das mães disseram ser favoráveis à TANU, argumentando que, se tiver algum problema, já pode tratar desde cedo; para poder saber se a criança tem algum 
problema no ouvido; para saber se o bebê escuta ou é surdo; e 2 dentre as 38 mães participantes relataram que eram favoráveis à TANU desde que os seus bebês passassem nos testes.

Os dados quanto às sugestões dadas pelas famílias a respeito da TANU foram coletados por meio da questão: "O que você melhoraria no Programa de Triagem Auditiva?” - 79\% das mães responderam que há necessidade de melhorar a orientação; receber um folheto explicativo sobre o teste que pudesse ser levado para mostrar para a família; receber informações antes do teste da triagem; receber mais informações quanto ao teste; deveria ter mais aparelhos na maternidade para não precisar ir à clínica; gostaria que as pessoas que faz o teste fossem mais pacientes e tentassem mais; e $21 \%$ responderam que não melhorariam nada.

Quanto à questão "Você achou a informação dada a respeito do teste suficiente ou não? Você obteve respostas em eventuais perguntas?”, 47\% responderam que as informações recebidas foram suficientes, afirmando que obtiveram todas as respostas e que as profissionais explicaram muito bem sobre todo o processo do programa. Entretanto, $53 \%$ das mães referiram que a informação recebida foi insuficiente, relatando: elas explicaram e eu não entendi; fiquei muito preocupada e nervosa; fiquei com muitas dúvidas; não lembro direito o que elas falaram; ela não respondeu tudo o que eu perguntei e saí com dúvidas.

Em relação à questão "Você gostaria de fazer algum comentário?”, 26\% disseram sim, afirmando que gostariam que o programa pudesse: melhorar a informação dada e o pai pudesse acompanhar o momento do teste; deveria ter mais explicações sobre o teste; apenas uma mãe dentre as 38 participantes relatou: elas me passaram muita segurança, me deixando calma, e 74\% não quiseram comentar. 
6 - DISCUSSÃO 



\section{6 - DISCUSSÃO}

No presente estudo enfocamos o grau de preocupação das mães durante o período que vai do teste ao reteste da TANU, com a comunicação do diagnóstico audiológico. Com isso é possível direcionar algumas tendências, tanto para a parte clínica como para o avanço científico, como já vêm realizando outros autores da área.

Como foi possível constatar na Tabela 1, a maioria dos participantes da pesquisa (39\% das mães seguidos de $26 \%$ dos pais) tem apenas o primeiro grau incompleto. Esse dado não só demonstra a realidade do ensino no nosso país, como nos faz pensar na dificuldade que essas pessoas certamente possuem para entender as informações e devolutivas dos resultados do teste da triagem auditiva. Corroborando com o estudo de CLEMENS; DAVIS; BAILEY ${ }^{8}$ et al. ${ }^{7}, 2000$, que justifica o grau de instrução da mãe como um dos fatores que intensifica a ansiedade.

Sobre essa questão, há um agravante, apresentado na Tabela 2, que indica a distribuição do número de filhos para cada participante, mostrando que a maioria (55\%) eram mães pela primeira vez; ou seja, elas estavam aprendendo a desempenhar a função materna e, certamente, apresentariam dificuldades para lidar e entender seus bebês. Diante disso, qualquer dúvida a respeito da saúde destes poderia vir a ocasionar preocupações, ansiedades, aflições e estresses. Esse dado está de acordo com estudos que referem que o grau de preocupação, estresse ou ansiedade é maior em mães de filhos únicos (VORH; LETOUNEAU; MCDERMOTT ${ }^{37}$, 2001, GRACEY ${ }^{15}, 2003$, RIBEIRO $\left.^{33}, 2005\right)$.

Nas Tabelas 3, 4, 5, 6 e 7, observamos que, no geral, os parâmetros estão dentro da normalidade: a média da idade gestacional foi de 38 semanas, 69\% das mães referiram não ter apresentado intercorrência gestacional, 54 \% referiram ter tido parto cesárea e a média do peso dos bebês ao nascimento foi de $2,889 \mathrm{~g}$. Já com relação aos indicadores de risco para deficiência auditiva, 51\% dos bebês não os apresentaram, enquanto $49 \%$ apresentaram um ou mais. Esses dados estão de acordo com os diagnósticos dos bebês, pois, após o reteste, 19 deles foram encaminhados para acompanhamento diagnóstico, 18 receberam alta e dois foram diagnosticados com perda auditiva. As mães de ambos afirmaram, categoricamente, NÃO para a questão: "Você 
acha que o seu bebê ouve bem?", indicando que, talvez, a triagem auditiva tenha levado-as a observarem melhor as reações auditivas de seus bebês frente aos sons, percebendo que havia algo de errado e desenvolvendo suas próprias suspeitas.

Podemos pensar, então, que, antes da TANU, os pais tendiam a desenvolver tardiamente uma suspeita de deficiência auditiva por meio da observação e interação com os seus bebês (LUTERMAN; KURTZER-WHITE ${ }^{23}$, 2003). Com o advento da TANU, o tempo para esse diagnóstico não só tende a diminuir, como também os pais, mesmo não entendendo corretamente as informações dadas, parecem ter mais condições de observar as reações auditivas de seus bebês.

Em síntese, embora não tenhamos observado relação significativa entre indicadores de risco, nível de escolaridade, número de filhos e o grau de preocupação materna, foi possível constatar a seguinte tendência: quando não havia indicador de risco, o grau de preocupação foi menor; quanto menor a escolaridade, maior foi o grau de preocupação, e quanto menor o número de filhos, maior foi o grau de preocupação (Tabela 9). Como já relatado acima, essa tendência não nos surpreendeu, estando de acordo com o estudo de VOHR; LETOUNEAU; MCDERMOTT $^{37}$, 2001, segundo o qual $16 \%$ das mães com filhos únicos apresentaram um nível de preocupação maior quando comparado às mães com mais de um filho, que foi de $9 \%$.

Entretanto, o fator mais relevante neste estudo foi o aumento do grau de preocupação, entre o teste e o reteste da triagem auditiva (Tabela 8), devido à falta de conhecimento dos pais sobre a TANU e ao fato de as informações a eles fornecidas terem sido consideradas insuficientes. Essa falta de informação sobre a TANU pode causar o aumento do grau de preocupação podendo, muitas vezes, prejudicar as etapas do programa, até mesmo causando o abandono dessa família durante o diagnóstico audiológico do seu bebê (HERGILS; HERGILS ${ }^{17}$, 2000, WEICHBOLD; WELZLMULLER $^{41}$, 2001, VORH; LETOUNEAU; MCDERMOTT ${ }^{37}$, 2001, WEBER; DIEFENDORF $\left.^{41}, 2001\right)$.

Por outro lado, o estudo de YOSHINAGA-ITANO ${ }^{43}, 2001$, refere que o grau de preocupação dos pais frente à TANU é considerado baixo, sendo que quando eles são acompanhados desde o início, o sofrimento dessa família é logo superado. 
Segundo LUTERMAN; KURTZER-WHITE ${ }^{23}$, 2003, logo após o parto, os pais estão buscando suas identidades frente ao novo papel que irão desempenhar na estrutura familiar. Nesse momento, recebem várias orientações, por exemplo, como amamentar, como devem ser os cuidados com o umbigo, como deve ser dado o banho no bebê, quais os exames que deverão ser realizados, incluindo a TANU; ou seja, são várias informações novas e difíceis de serem memorizadas. Devemos, então, tomar todo o cuidado, explicando sobre a TANU de uma forma clara, com linguagem simples, repetindo e/ou reformulando o quanto for necessário, pois esse momento será fundamental para a família entender a importância da audição para o desenvolvimento do seu bebê, e também para que ela não interrompa o processo diagnóstico, deixando de comparecer ao programa.

Como vimos, o resultado referente à preocupação materna no período entre o teste e o reteste da TANU foi o seguinte: $42,1 \%$ das mães estavam preocupadas ou muito preocupadas durante o primeiro teste da triagem, sendo que o grau dessa preocupação aumentou para 62,2\% no reteste, o que está de acordo com o estudo de VOHR; LETOUNEAU; MCDERMOTT ${ }^{37}, 2001$.

Alguns autores relatam que o aumento ocasional da preocupação é positivo, pois pode otimizar o processo diagnóstico, fazendo com que essas mães dêem continuidade a ele, assim diminuindo as faltas e abandonos (WEICHBOLD; WELZLMULLER $\left.^{40}, 2000\right)$. Entretanto, outros autores relatam que pouca atenção dada referente as reações da família após o resultado de não passou do teste, pode até mesmo causar danos para o programa (YOUNG; ANDREWS ${ }^{45}, 2001$, PICTON; HYDE ${ }^{30}, 2004$ ).

De fato, durante o nosso estudo, as mães nos relataram que somente retornaram ao programa devido à preocupação instalada sobre a audição dos seus bebês. Isso está de acordo com estudos que asseguram que a não preocupação materna quanto ao resultado do teste e/ou reteste da triagem auditiva pode ser desfavorável, podendo levar ao abandono do programa (WEICHBOLD; WELZL-MULLER ${ }^{41}$, 2001; MANFREDI $^{24}, 2001$; CROCKETT et al. ${ }^{11}$, 2006).

$\mathrm{Na}$ Tabela 10 observamos que a maioria das mães (89\%) deste estudo em nenhum momento pensou em não levar o seu bebê para o diagnóstico, sendo que a maioria justificou achar necessário efetivá-lo, demonstrando medo de existir um 
problema e o bebê ficar sem tratamento. Entretanto, 11\% das mães pensaram em não dar continuidade à avaliação audiológica, argumentando dificuldade para voltar ao programa, perda de tempo ou medo da confirmação de um problema. Mesmo assim, retornaram, segundo elas, pelo fato de terem ficado preocupadas. Também MANFREDI $^{24}, 2001$, observou em seu estudo que 30,8\% das mães sinalizaram pouca importância à triagem auditiva e ao seguimento do processo diagnóstico, justificando a ausência devido ao esquecimento e/ou perda do horário e até mesmo relatando ter testado a audição em casa.

Outros estudos são necessários para analisarmos e comprovarmos se realmente o grau de preocupação, ocasional, ajuda na continuidade de todo o processo da TANU. Mas, mesmo assim, no presente estudo observamos que cinco mães referiram que o grau de preocupação entre o teste e o reteste diminuiu devido às informações suficientes e claras recebidas, não as deixando com dúvidas a respeito da importância do diagnóstico audiológico. Isso está em consonância com o estudo realizado por HERGILS; HERGILS ${ }^{17}$, 2000, em que, das 64 mães-respondentes, apenas 10 fizeram comentários positivos referentes às informações dadas em relação ao teste da TANU. No entanto, mesmo relatando a diminuição do grau de preocupação entre o teste e o reteste, essas mães voltaram ao programa para realizar a avaliação audiológica, deixando evidente que isso ocorre em razão de as informações terem sido adequadamente veiculadas e compreendidas.

Embora os profissionais da equipe da TANU tenham todo o cuidado no momento da orientação (Anexo 6 - capítulo orientação), há necessidade de capacitá-los ainda mais, a fim de que saibam fornecer clara e adequadamente as informações neste momento de reações, como preocupação, ansiedade, estresse, que podem desencadear raiva do processo diagnóstico e até mesmo dos profissionais envolvidos (STUART; MORETZ; YANG ${ }^{36}$, 2000, PIPP-SIEGEL; SEDEY; YOSHINAGA-ITANO ${ }^{31}, 2002$, LUTERMAN; KURTZER-WHITE ${ }^{23}$, 2003, DesGEORGES ${ }^{13}$, 2003, POULAKIS; BARKER; WAKE ${ }^{32}, 2003$, RUSS et al. ${ }^{34}, 2004$, CROCKETT et al. ${ }^{10}, 2005$ ).

A Tabela 11 mostra o conhecimento materno sobre o teste da triagem: $50 \%$ das mães ficaram sabendo do programa TANU no momento da alta hospitalar, $34 \%$, durante a internação e $16 \%$, antes. Relacionando o momento da informação sobre a TANU e o grau de preocupação materna, foi observada significância estatística $(H=$ 
10.73; $p=0.005)$ na diferença entre grau de preocupação das mães que foram informadas sobre a triagem no momento da alta hospitalar e grau de preocupação daquelas que foram informadas antes da internação, sendo que o primeiro foi maior que o segundo. Outros estudos também observaram o mesmo: OLIVEIRA; ZANELLI; MAINARDI $^{29}, 1998$, WEICHBOLD; WELZL-MULLER $^{41}$, 2001, CLEMENS; DAVIS; BAILEY $^{8}, 2002$.

Sobre o profissional responsável por informar sobre a TANU, no presente estudo, 37\% das mães relataram que foi a enfermeira da maternidade que forneceu essa informação. Em relação ao que esperavam no primeiro teste, $61 \%$ disseram que era a avaliação de audição de seu bebê e $36 \%$ relataram não saber o que esperar. Do total de mães-respondentes, $60 \%$ afirmaram que não ficaram preocupadas ao saber que os seus bebês deveriam fazer o teste da triagem auditiva, e 92\% lembravam do que tinha sido dito a elas após o primeiro teste, como a possibilidade de o resultado dar falso-positivo em razão da presença de vernix, respiração ruidosa, ou mesmo devido ao bebê estar acordado e se mexer. Podemos concluir que, apesar deste último número, as mães não se lembravam que haviam sido informadas sobre a prática do reteste, quando necessária; ou seja, de que se trata de uma situação relativamente comum com os recém-nascidos nos primeiros dias de vida.

Ainda sobre as informações disponibilizadas, embora faça parte da rotina do projeto "Modelo de Saúde Auditiva no Recém-nascido" (anexo 6) a orientação oral e o fornecimento de folhetos informativos, que destacam a importância, a data, o horário e o local da triagem auditiva, $100 \%$ das mães deste estudo afirmaram que não receberam nenhum tipo de folheto explicativo sobre o teste da TANU. Na literatura, encontramos várias pesquisas em que esses folhetos foram disponibilizados e considerados úteis para os participantes dos programas de triagem auditiva (VOHR; LETOUNEAU; McDERMOTT $^{37}, 2001$, ARNOLD et al. ${ }^{2}, 2006$, ARNOLD et al. $\left.{ }^{3}, 2006\right)$.

No que se refere ao reteste, $84 \%$ das mães deste estudo esperavam que a audição de seus bebês fosse testada, sendo que a maioria (92\%) afirmou ter sido informada sobre o resultado do reteste. Entretanto, 55\% disseram não saber qual o profissional que tinha realizado a triagem auditiva no seu bebê (Tabela 12). Esse é um dado importante, pois evidencia que aqueles que aplicaram os testes não se apresentaram às mães, o que vai contra a prática humanista de acolher as famílias do 
programa, visando estabelecer confiabilidade para, então, informá-las e orientá-las devidamente. A simples atitude de se apresentar como um profissional de saúde, fonoaudióloga (o), poderá fazer com que a mãe se sinta mais segura para dar continuidade ao processo, caso seja necessário. Devemos, assim, nos preocupar com a formação e a capacitação da equipe dos profissionais da TANU, a fim de proporcionar uma melhor interação pais-profissional (OLIVEIRA; ZANELLI; MAINARDI ${ }^{29}, 1998$, LUTERMAN; KURTZER-WHITE ${ }^{22}$, 1999, WEBER; DIEFENDORF ${ }^{41}$, 2001, DesGEORGES ${ }^{13}, 2003$, HYDE $\left.^{18}, 2005\right)$.

Outro aspecto a se ressaltar diz respeito à atitude dos familiares frente à possibilidade de o bebê ser diagnosticado como deficiente auditivo. Constatamos que, sem saber ao certo o que esperar e o que fazer, as mães intuitivamente batiam palmas, tampas de panelas, portas, ligavam rádio em volume alto, gritavam, para poderem observar reações auditivas nos seus bebês. Também CLEMENS; DAVIS; BAILEY ${ }^{8}$, 2000, relataram ações semelhantes para testar a audição, como falar mais alto e bater palmas. Isso nos mostra que a falta de informações sobre a audição e o seu papel no desenvolvimento infantil, somada ao grau de preocupação, pode fazer com que as mães procurem formas de testar seus bebês em casa, deixando muitas vezes de dar continuidade ao programa.

Na Tabela 13 observamos a relação entre o grau de preocupação e o momento em que a mãe ficou sabendo sobre a TANU, verificou-se presença de significância em relação ao aumento do grau de preocupação quando as mães souberam da TANU depois da alta hospitalar, demonstrando que, para não causar preocupação na família, é necessário orientá-las e informá-las claramente a respeito do procedimento do programa antes da internação hospitalar.

Assim, na Tabela 14 observamos que a maioria das mães (87\%) acreditava que o seu filho ouvia e 100\% consideravam importante que isso ocorresse, embora a maioria (14 mães) não soubesse justificar por que. Apenas três mães afirmaram não terem percebido se os seus bebês ouviam, pois não sabiam o que e como observar. Isso mostra a importância de esclarecê-las sobre a função da audição, como também ressaltam STUART; MORETZ; YANG ${ }^{36}$, 2000, CLEMENS; DAVIS; BAILEY ${ }^{8}, 2000$. 
Não podemos deixar de salientar que essa preocupação frente ao processo do diagnóstico audiológico e a falta de conhecimento da audição do seu bebê, ou mesmo, como observar as reações auditivas do bebê podem causar um risco ao relacionamento pais-bebê (LUTERMAN; KURTZER-WHITE ${ }^{22}$, 1999, WEICHBOLD; WELZL-MULLER ${ }^{40}$, 2000, STUART; MORETZ; YANG ${ }^{36}, 2000$, GRACEY $^{15}, 2003$, LUTERMAN; KURTZER-WHITE ${ }^{23}, 2003$, POULAKIS; BARKER; WAKE ${ }^{32}, 2003$ ).

O presente estudo também está de acordo com as conclusões de HERGILS; HERGILS $^{17}$, 2000, de que as experiências, questões, opiniões, informações e os pensamentos insuficientes a respeito da TANU fazem com que as mães reajam de uma forma insatisfatória ou mesmo apresentem um aumento do grau de preocupação. Assim, quando se trata da saúde do recém-nascido, não podemos esquecer da família, que é constante nos cuidados a ele fornecidos, como também afirmam DesGEORGES ${ }^{13}$, 2003, GRACEY ${ }^{15}, 2003$.

Vários estudos que visam melhorar o programa da TANU sugerem que devem ser encontradas formas de assegurar que as famílias compreendam a necessidade da continuação e conclusão do diagnóstico audiológico e, quando necessário, da intervenção precoce. Os pais devem ser informados sobre os resultados de forma coesa, clara e objetiva, sendo que não podem restar dúvidas quanto a questões emergentes no contexto do processo (HERGILS; HERGILS ${ }^{17}, 2000, \mathrm{BAROCH}^{5}, 2003$, NG et al. ${ }^{27}$, 2004, STOOL $\left.{ }^{35}, 2004, \mathrm{HYDE}^{18}, 2005\right)$. Assim todas as etapas de um programa de saúde auditiva devem estar bem definidas e articuladas entre si, garantindo sua eficácia (RUSS et al. ${ }^{34}, 2004$, RIBEIRO $^{33}, 2005$, HYDE $^{18}, 2005$ ).

O presente estudo concorda com os autores que ressaltam a importância de se investigar mais para padronizar tanto o folheto explicativo quanto o questionário com perguntas referentes às reações e atitudes dos pais frente à TANU. Com isso, será possível viabilizar dados epidemiológicos de suporte à família dentro do contexto do programa, bem como disseminar informações e aprimoramentos necessários (VOHR; MOORE; TUCKER ${ }^{38}, 2002$, YOUNG; TARTTERSALL ${ }^{46}, 2005$, ARNOLD et al. ${ }^{2,3}$ 2006.

Embora a intervenção fonoaudiológica junto à família durante o processo de triagem auditiva continue sendo uma área abrangente, ficou aqui evidenciada a 
importância de mais investigações sobre o tema, que visem diminuir o grau de preocupação materna, garantindo a informação adequada sobre o programa e sobre a audição do bebê. Com isso, certamente será possível minimizar as faltas das famílias no processo diagnóstico. Também é fundamental viabilizar e elaborar um protocolo, padronizado e validado cientificamente, de informação e orientação sobre a importância da audição e da triagem auditiva. 
7 - CONCLUSÕES 



\section{7 - CONCLUSÕES}

Os achados obtidos neste estudo evidenciam que:

- A preocupação materna aumentou entre o teste e o reteste da triagem auditiva;

- Há falta de conhecimento familiar a respeito da TANU;

- Há carência de conhecimento familiar quanto à importância da audição para o desenvolvimento de linguagem, de fala e cognitivo da criança;

- Faz-se necessária a introdução de um folheto explicativo antes do teste da triagem ou mesmo para ser entregue à família no momento da alta hospitalar.

Ainda que sejam necessárias mais pesquisas sobre o tema, o presente estudo indica o quanto é imprescindível que, durante o processo diagnóstico do Programa TANU, a família tenha acesso a um protocolo padronizado e validado de intervenção fonoaudiológica. Esse procedimento pode trazer contribuições teóricas e metodológicas, especialmente no delineamento de estratégias de informações e orientações para o acompanhamento e acolhimento dos familiares. 

ANEXOS 

ANEXO 1 - Parte 1 - Questionário aplicado em Rhode Island Hearing Assesment Program

\section{Rhode Island Hearing Screen Program Questionnaire}

Today's Date:

Your Child's Date of Birth:

Mother's Med.Rec.\#:

Sex: $\quad \mathrm{M}$ or $\mathrm{F}$

Gest. Age (w):

Birthweight (g):

\section{A. Screening Program Questions}

1. a. How many children are in your family?

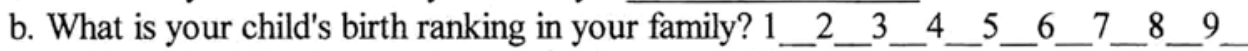

(Example: The oldest child in a family with 3 children is 1. )

2. When did you learn that your baby's hearing was being screened?

1 aware before hospital admission

2 aware during hospital admission

3 aware after hospital discharge

4 don't remember

3. If you learned about the screen after discharge, who informed you?

1 my or other pediatrician

2 RIHAP data staff

3 audiologist

4 other

5 don't remember

9 not applicable

4. Were you worried about the test when you were told?

1 yes
2 no
3 don't remember

5. Do you remember what you were told?

1 yes

2 no

6. How anxious or worried were you about the hearing screen?
1. not worried
2. mildly worried
3. somewhat worried
4. worried
5. very worried

7. Did you receive a brochure about the screen program?

1 yes

2 no

3 don't remember 
8. If yes, was the brochure helpful?

1 yes
2 no
9 not applicable

8b. Do any family members have a hearing loss?

$$
\begin{aligned}
& 1 \text { yes } \\
& 2 \text { no }
\end{aligned}
$$

If yes, which ones?

$\begin{array}{lll}\text { Mother's side: } & \begin{array}{l}\text { self (mother) } \\ \text { grandmother } \\ \text { sister } \\ \text { aunt } \\ \text { niece }\end{array} & \begin{array}{l}\text { grandfather } \\ \text { brother } \\ \text { uncle } \\ \text { nephew }\end{array} \\ \text { Baby's father's side: } & \begin{array}{l}\text { self (baby's father) } \\ \text { grandmother } \\ \text { sister } \\ \text { aunt } \\ \text { niece }\end{array} & \begin{array}{l}\text { grandfather } \\ \text { brother } \\ \text { uncle } \\ \text { nephew }\end{array} \\ \end{array}$

Do any of these family members wear hearing aids? Which ones? 
ANEXO 1 - Parte 2

\section{$\underline{\text { Rhode Island Hearing Screen Program Questionnaire }}$}

Today's Date:

Your Child's Date of Birth:

Your Date of Birth:

Sex: $\mathrm{M}$ or F

Mother's Med.Rec.\#:

Gest. Age(w):

Birthweight (g):

\section{B. Rescreen Appointment Questions}

9. What did you expect to happen at the rescreen appointment?

1 hearing test

2 didn't know what to expect 3 other 9 not applicable

10 . Were you given any results at the rescreen appointment?

1 yes
2 no
3 partial
4 don't remember
$\quad 9$ not applicable
explain

11. Do you know what kind of trained staff performed the rescreen? 1 screening technician 2 nurse 3 audiologist 4 don't know 9 not applicable

12. How worried/anxious were you about the rescreen test?
1. not worried
2. mildly worried
3. somewhat worried
4. worried
5. very worried
6. don't remember
9. not applicable

13. How would you improve the statewide screening program? 
ANEXO 2 - Questionário aplicado na University Hospital, Linköping-Suécia

Person-nr
Namn
Adress
Postadress

\section{Angående hörselundersökningen av ert barn på BB}

Som en del av den hälsokontroll som görs av alla spädbarn på BB fick ert barn även vara med om en hörselundersökning. Vi vill nu en tid efteråt få era synpunkter på den delen av hälsokontrollen, eftersom det är en utvidgning av tidigare hälsoundersökning.

1. Hur upplevde du/ni den hörselundersökning som gjordes?

2. Några funderingar som undersökningen gav upphov till?

3. Ardu/ni positiva eller negativa till denna undersökning? Motivera helst!

4. Var informationen om undersökningen tillräcklig? Fanns möjlighet att fả svar på eventuella frågor?

5. Ytterligare kommentarer?

Tack för er medverkan!

Leif Hergils, Bitr överläkare, Hörselvården, US 
ANEXO 3 - Questionário utilizado para a coleta de dados do presente estudo

\section{QUESTIONÁRIO \\ PROGRAMA DE TRIAGEM AUDITIVA NEONATAL UNIVERSAL}

Data:

Data de Nascimento do bebê:

Nome do bebê:

Idade Gestacional:

Gênero: ( ) Masculino （）Feminino

Intercorrência Gestacional:

Parto: ( ) Cesárea ( ) Normal Peso no nascimento:

UTI : ( ) Sim （ ) Não Porquê? ___ Período:

Mãe: __ Idade:

Escolaridade: Profissão:

Pai: Idade:

Escolaridade: Profissão:

A- Questões do Programa de Triagem

1- a) Quantos filhos você tem?

b) Qual é o lugar de nascimento do seu bebê ? $1 \_2 \_3 \_4 \_5 \_6$

(Exemplo: Uma família com 3 crianças a criança mais velha é 1)

2- Quando você soube que o seu bebê iria fazer triagem auditiva?

( ) soube antes da internação no hospital.

( ) soube durante a internação no hospital

( ) soube depois da alta hospitalar

( ) não me lembro.

3- Quem foi que te informou?

( ) meu pediatra ou o pediatra de plantão.

( ) enfermeira

( ) fonoaudiólogo

( ) outro

( ) não lembro.

( ) não foi aplicado.

4- Você ficou preocupado(a) quando soube do teste?

( ) $\operatorname{sim}$

( ) não

( ) não lembro 
5- Você lembra o que foi dito a você?

( ) sim

( ) não

6- Como você ficou ao saber da triagem auditiva, preocupado(a) ou ansioso(a)?

( ) não preocupado

( ) ligeiramente preocupado

( ) um pouco preocupado

( ) preocupado

( ) muito preocupado.

7- Você recebeu folheto sobre o programa de triagem auditiva?

( ) $\operatorname{sim}$

( ) não

( ) não lembro.

8- Se sim, foi um folheto útil?

( ) sim

( ) não

( ) não aplicável

8b- Alguém da família tem perda auditiva?

( ) sim

( ) não

Se sim, quem ?

Materno mãe (do bebê)

$\begin{array}{ll}\text { avó } & \text { avô } \\ \text { irmã } & \text { irmão } \\ \text { tia } & \text { tio }\end{array}$

sobrinha sobrinho

Paterno pai (do bebê)

avó avô

irmã irmão

tia tio

sobrinha sobrinho

Algum desses da família usa aparelho auditivo? Quem?

B- Questões sobre consulta do reteste

9- O que você esperava acontecer na consulta de reteste?

( ) teste auditivo

( ) não sabia o que esperar

( ) outro

( ) não aplicável 
10- Foi dado a você algum resultado na consulta do reteste?
( ) sim
( ) não
( ) parcial
( ) não lembro
( ) não aplicável
explique

11- Você sabe quem fez o reteste?

( ) técnico em triagem

( ) enfermeiro

( ) fonoaudiólogo

( ) não sei

( ) não aplicável

12- Como você ficou a respeito do reteste, preocupado(a)?

( ) não preocupado(a)

( ) ligeiramente preocupado(a)

( ) um pouco preocupado(a)

( ) preocupado(a)

( ) muito preocupado(a)

13- O que você melhoraria no Programa de Triagem Auditiva?

14- Qual foi a sua experiência a respeito da triagem auditiva neonatal?

15- Com a triagem auditiva surgiram algumas questões ou pensamentos?

16- Você é favorável ou não a este teste? Por favor, explique.

17- Você achou a informação dada a respeito do teste suficiente ou não? Você obteve respostas em eventuais perguntas? 
18- Você gostaria de fazer mais alguns comentários?

19- Em algum momento você pensou em NÃO trazer o seu bebê para o diagnóstico auditivo?

( ) sim

Por quê?

( ) medo da confirmação de um problema

( ) por achar desnecessário

( ) por dificuldades de voltar ao programa

( ) outro

( ) não

Por quê?

( ) medo de existir um problema e o bebê ficar sem tratamento

( ) por achar necessário

( ) por ser gratuito

( ) outro

20- Você acha que o seu bebê ouve bem?

( ) $\operatorname{sim}$

( ) não

21-Você acha importante o bebê ouvir?

( ) sim

( ) não

Porquê?

22- Você já conseguiu perceber se o seu bebê ouve?

( ) $\operatorname{sim}$

( ) não

Exemplifique:

23- Quem lhe informou sobre a triagem?

( ) obstetra do pré natal

( ) enfermeira do pré natal

( ) enfermeira da maternidade

( ) pediatra da maternidade

( ) pediatra do posto

( ) fonoaudiólogo

( ) amigos Quem?

( ) agente do PSF

( ) outro

( ) não lembro.

( ) não foi aplicado. 
24- $O$ que você esperava encontrar no teste da triagem auditiva?

( ) teste auditivo

( ) não sabia o que esperar

( ) outro

( ) não aplicável 
ANEXO 4 - Revisão de literatura, complementar, sobre questionário enquanto instrumento de pesquisa.

\section{Questionário como instrumento de pesquisa}

Destacamos aqui alguns autores que têm refletido sobre as possibilidades do uso do questionário como instrumento de coleta de dados.

De início, podemos citar TANAKA; $\mathrm{MELO}^{47}, 2001$, que se preocuparam em precisar os termos técnicos utilizados para definir instrumentos de pesquisa, os tipos de questões que podem ser elaboradas e seus efeitos no estudo. Assim, para os autores, geralmente se usa "questionário" para designar qualquer instrumento de coleta de informações; entretanto, quando preenchido pela população alvo da avaliação, o termo técnico correto é formulário. Para elaborar um questionário, deve-se ter em mente a necessidade de que as questões sejam concretas e específicas, o que permite que as respostas também sejam objetivas. As questões podem ser fechadas, tendo como vantagem a permissão de respostas padronizadas que permitam a comparação com outras avaliações; entretanto, há desvantagens nesse procedimento, como facilitar a resposta para um informante que não saberia responder. Já as questões abertas possibilitam ao pesquisador obter respostas mais completas do informante sobre o tema. De qualquer forma, o pesquisador deve sempre evitar interferir nas respostas.

Para GÜNTHER ${ }^{16}$, 1999, ao elaborar um questionário, sendo este o instrumento principal para o levantamento de dados, deve-se pensar em alguns princípios, como: bases conceituais e populacionais; contexto social da aplicação; estrutura lógica do instrumento; elementos do instrumento (questões e itens); diferenças de aplicação, tais como: entrevista individual, pelo telefone, por correio convencional ou eletrônico, ou em grupos.

Sobre as bases conceituais, o autor adverte que devemos refletir sobre qual é o objetivo da pesquisa e quem é o público-alvo, pois essa reflexão leva, necessariamente, à relação conceito/item e à relação público-alvo/amostra, sendo o objetivo determinante dos conceitos a serem investigados numa coleta de dados. 
Nessa perspectiva, uma escolha importante no desenvolvimento dos itens diz respeito ao tipo de perguntas: fechadas e/ou abertas. As perguntas fechadas devem ser usadas quando se conhecem os tópicos de uma temática, principalmente quando existe pouco tempo para a aplicação do instrumento. Já as perguntas abertas servem para capturar justamente aquelas opiniões não asseguradas pelos itens fechados, reforçando, assim, a percepção dos respondentes de que o pesquisador tem interesse na opinião dele.

$\mathrm{O}$ autor afirma que existe uma interdependência entre a elaboração do instrumento e a estratégia de sua aplicação, sendo que é o grau de complexidade que determina o número de itens e a forma de apresentação, a reciprocidade entre o públicoalvo e os conceitos a serem investigados.

A estrutura e a seqüência das perguntas contribuem significativamente para diminuir o esforço mental do respondente, além de assegurar que todo o tema (objetivo) seja tratado numa ordem que sugira uma "conversa com objetivo", permitindo ao respondente revelar algo sobre si mesmo. Com isto, a obtenção dos dados irá variar conforme a situação, relevância, sensitividade temática e a inter-relação de confiança de ambos (pesquisador-respondente).

O autor conclui que, para a efetividade da aplicação do instrumento, é necessário que, além da escolha das palavras para o direcionamento das respostas, o pesquisador se preocupe com o nível educacional dos respondentes, pois a linguagem não pode ser complexa nem simples demais. Para chegar a uma adequação quanto a esse aspecto, é necessário realizar um estudo piloto. O questionário é, pois, um conjunto de perguntas sobre um determinado tema que não testa a habilidade do respondente, mas mede a sua opinião, seus interesses, aspectos da personalidade e informação biográfica.

Os princípios básicos de elaboração de um questionário, segundo outro autor, $\mathrm{BABBIE}^{4}$, 2003, são: o formato em geral, a utilização de comentários introdutórios, instruções básicas de preenchimento ou instruções específicas, montagem e seqüência (ordenação) das questões, formatos para respostas, entre outros.

O autor afirma que as perguntas fechadas dão maior uniformidade de respostas e são facilmente processadas, enquanto as questões abertas são mais 
específicas e oferecem uma grande diversidade de respostas. Por fim, ressalta que as categorias e questões, assim como a ordenação e estruturação das questões adaptadas ou criadas especificamente para o questionário devem ser feitas considerando-se os cuidados necessários para a aplicação do instrumento.

A tendência atual é, então, combinar diferentes métodos e instrumentos de investigação na realização das pesquisas, pois, segundo GOMES DE OLIVEIRA ${ }^{14}$, 2004, para cada assunto que se pretende estudar existe uma metodologia ou instrumento mais adequado. Diante disso, o pesquisador tem de ter consciência de sua opção e reflexão metodológica, para identificar as necessidades de sua pesquisa dentro de um determinado contexto e situação.

A autora enfatiza, ainda, que o questionário e as entrevistas precisam se ancorar em categorias, sendo que estas, quando bem definidas, asseguram a consciência dos dados e potencializam a densidade da análise e interpretação dos mesmos por meio da estruturação de eixos de análise. Assim, é possível perceber que a necessidade do rigor e a complexidade no uso do questionário como instrumento de pesquisa aparecem não só no momento de elaboração de suas categorias, das questões e das opções de respostas, como também se revelam no momento de leitura e análise de dados. 
ANEXO 5 - Carta de Informação ao Sujeito e Termo de Consentimento Livre-Esclarecido

\section{CARTA DE INFORMAÇÃO AO SUJEITO DA PESQUISA}

Prezados pais e/ou Responsáveis,

$\mathrm{O}$ (a) senhor(a) está sendo convidado(a) a participar dessa pesquisa que tem como título: "Intervenção fonoaudiológica junto à família durante um programa de triagem auditiva neonatal universal", a ser realizada na Clínica de Audiologia Infantil, com horário agendado e duração de 30 minutos, aproximadamente.

O estudo tem como objetivo identificar estratégias de orientação para a família, a partir das suas respostas, a fim de acolher melhor as suas necessidades neste período de diagnóstico audiológico do seu fillho(a).

Será realizada uma entrevista, na qual o senhor(a) será solicitado(a) a responder a um questionário sobre o Programa de Triagem Auditiva Neonatal Universal, no qual constam: questões a respeito de informações gerais sobre seu filho(a) e sobre a sua família e questões relacionadas à pesquisa.

O registro das respostas será por meio de folha sulfite e pelo gravador de voz Digital Voice Recorder VN-480PC-Olympus, para posterior análise. Esta gravação será ouvida pela pesquisadora e pelos membros autorizados do grupo de pesquisa.

Os resultados deste estudo poderão ser publicados em jornais e revistas profissionais ou apresentados em congressos profissionais, e neste último caso, sua gravação poderá ser utilizada para ilustração, mas sua identidade não será revelada.

Não existe riscos ou desconfortos associados a este estudo, pois sua participação ficará restrita à gravação de suas respostas. Entretanto, os resultados deste estudo podem ajudar os pesquisadores a esclarecer as maiores dificuldades enfrentadas pelas famílias durante o diagnóstico audiológico de seu filho(a) e o quê pode ser feito para orientá-las e auxiliá-las.

Cabe a pesquisadora cumprir de forma ética as informações declaradas nesta carta e estar disponível a qualquer momento para esclarecimento de possíveis dúvidas.

Esta pesquisa será publicada oficialmente como Dissertação de Mestrado, contudo disponho-me a esclarecer, informar sobre o questionário e realizar as orientações necessárias em cada caso.

Caso os pais e/ou responsáveis queiram apresentar reclamações em relação a sua participação na pesquisa, poderão entrar em contato com o Comitê de Ética em Pesquisa em Seres Humanos, da FOB-USP, pelo endereço Alameda Dr. Otávio Pinheiro Brizola $n^{\text {o }}$ 9-75 telefone: (014) 3235-8000.

Bauru,

Nome do sujeito ou responsável:

Assinatura do sujeito ou responsável:

Nome do pesquisador responsável: Fga Simone Virginia Vitti

Assinatura do pesquisador responsável: 


\section{TERMO DE CONSENTIMENTO LIVRE E ESCLARECIDO}

Pelo presente instrumento que atende às exigências legais, o Sr. (a) da cédula de identidade _ _ ${ }^{*}$ responsável pelo paciente após leitura minuciosa da CARTA DE INFORMAÇÃO AO SUJEITO DA PESQUISA, devidamente explicada pelos profissionais em seus mínimos detalhes, ciente dos serviços e procedimentos aos quais será submetido, não restando quaisquer dúvidas a respeito do lido e explicado, firma seu CONSENTIMENTO LIVRE E ESCLARECIDO concordando em participar da pesquisa: "Intervenção fonoaudiológica junto à família durante um Programa de Triagem Auditiva Neonatal Universal" realizada por: Simone Virginia Vitti, $\mathrm{n}^{\mathrm{o}}$ do Conselho: 6718 /SP, sob orientação da $\operatorname{Prof}^{a} \operatorname{Dr}(a)$ : Maria Cecília Bevilacqua.

Fica claro que o sujeito da pesquisa ou seu representante legal pode a qualquer momento retirar seu CONSENTIMENTO LIVRE E ESCLARECIDO e deixar de participar desta pesquisa e ciente de que todas as informações prestadas tornaram-se confidenciais e guardadas por força de sigilo profissional.

Por estarem de acordo assinam o presente termo.

Bauru-SP, de de

Assinatura do Responsável

Assinatura do Pesquisador Responsável

\section{A SER PREENCHIDO, SE O SUJEITO DA PESQUISA NÃO FOR O PACIENTE.}

Nome do Pesquisador Responsável:

Endereço do Pesquisador Responsável $\left(\mathrm{Rua}, \mathrm{N}^{\circ}\right)$ :

\begin{tabular}{l} 
Cidade: $\quad$ Estado:_ CEP: \\
Telefones: \\
E-mails: \\
Endereço Institucional (Rua, $\left.\mathrm{N}^{\circ}\right):$ \\
\hline Cidade: \\
Telefone:
\end{tabular}


ANEXO 6 - Orientação dada aos pais durante o programa de triagem auditiva neonatal universal da FOB-USP, Bauru.

\section{MATERNIDADE: Rotina e Orientações}

Realizada por meio do teste de emissões otoacústicas evocadas transientes, a TANU é oferecida a todas as famílias de neonatos da Maternidade Santa Isabel de Bauru. De acordo com a direção clínica do hospital maternidade, a triagem auditiva está inserida no documento que todos os responsáveis pelos bebês assinam no momento da internação, autorizando a realização de todos os procedimentos clínicos que fazem parte da rotina de atendimento hospitalar.

A orientação aos familiares, especialmente à mãe, é imprescindível no programa de triagem auditiva neonatal, sendo realizada pela fonoaudióloga que atua no programa Porém, no caso de bebês que nascem no final de semana, assim como de algumas mães que recebem alta antes dos filhos realizarem a triagem, por exemplo, no período noturno, a orientação sobre a TANU é realizada pela Enfermeira (berçarista) que previamente foi orientada pela Equipe de Fonoaudiologia.

A rotina desenvolvida pelo programa ocorre diariamente, de segunda a sexta-feira. Inicialmente, é realizada a análise do prontuário médico do recém-nascido e preenchida uma ficha cadastral com os dados a respeito das condições gestacionais e do parto.

Em seguida, são selecionados os bebês a serem triados antes da alta hospitalar, ou seja, com pelo menos 24 horas de vida e que não estejam impossibilitados por se encontrarem em terapia intensiva. Após essa definição, a fonoaudióloga visita os leitos para informar e orientar as mães a respeito da importância da triagem auditiva, das condições ideais para a realização do exame, bem como sobre a possibilidade do reteste, caso as respostas auditivas não possam ser captadas, o que pode ocorrer pela presença de vernix no conduto auditivo externo nos primeiros dias de vida. Além disso, os familiares também são informados que o exame é indolor e não invasivo.

Os recém-nascidos são levados à sala de triagem pela mãe. Neste momento, é realizada uma breve anamnese a fim de se obter informações sobre gestação e também 
outras sobre antecedentes familiares que, geralmente, não constam no prontuário, como, por exemplo, histórico familiar de deficiência auditiva.

Imediatamente após o término da triagem auditiva, é dada a devolutiva para a mãe sobre os achados do exame, como descrito a seguir:

- No caso de presença das emissões otoacústicas (Resultado: passa) são dadas orientações, em linguagem simples, sobre os resultados do teste, assim como a respeito do desenvolvimento de audição e fala no primeiro ano de vida. Ressalta-se a importância da família acompanhar estes aspectos e a possibilidade de procurar a Equipe de Fonoaudiologia, caso seja notado algum indício de alteração auditiva ou de linguagem, ou, até mesmo, caso haja alguma dúvida a respeito do desenvolvimento da criança. Neste momento, a mãe é informada de que a equipe de Fonoaudiologia pertence ao Curso de Fonoaudiologia da Faculdade de Odontologia de Bauru-USP, bem como é explicada a localização e fornecido o telefone da Clínica de Fonoaudiologia da FOB-USP.

- No caso de não captação das emissões otoacústicas (Resultado: não passa), uni ou bilateralmente, a mãe é informada das possíveis razões desse resultado, como a presença de vernix, ruído excessivo durante o exame, respiração ruidosa, além de ser ressaltado que a prática do reteste faz parte do programa TANU, ou seja, que se trata de uma situação relativamente comum com os neonatos nos primeiros dias de vida. Em seguida, é agendada a data do retorno para que seja realizado o reteste, ainda na maternidade.

- No reteste da TANU a mãe é informada novamente sobre as condições ideais para realização do teste e que, por se tratar de um exame sensível, ainda pode haver influência dos fatores descritos anteriormente. Se, ao refazer o exame, for observada presença de emissões otoacústicas (Resultado: passa), a mãe é orientada de forma semelhante no momento do teste. E caso ainda não seja observada resposta (Resultado: não passa), o bebê será encaminhado e a mãe orientada a respeito do protocolo do Programa de Saúde Auditiva Neonatal proposto pela FOB-USP. Ou seja: nos casos em que, no reteste, ainda não são captadas as respostas 
auditivas, os recém nascidos são encaminhado para avaliação audiológica, a ser realizada na Clínica de Audiologia Infantil da Faculdade de Odontologia de Bauru - USP. Isso ocorre pela disponibilidade, nessa clínica, de exames adicionais mais completos e também pela presença do médico otorrinolaringologista que realiza a avaliação clínica. Novamente, é dito que todos os exames são indolores e não invasivos, bem como é reforçado que todos os procedimentos são realizados por meio do SUS.

A orientação sobre a TANU é realizada juntamente com todas as outras, comuns no momento da alta, por exemplo, o Teste do Pezinho. Nesse momento as observações são mais gerais, enfocando a existência da TANU na rotina do hospital para todos os recém nascidos, o objetivo e a importância do exame que será realizado por meio do SUS, não havendo, assim, custo direto aos pais. Além disso, as mães recebem um cartão explicativo com a data de agendamento da TANU, que contém informações básicas sobre esse procedimento.

No caso dos recém-nascidos que obtiveram resultado não passa na TANU, no momento da alta a enfermeira também reforçará a orientação sobre o reteste, a data do agendamento, também entregando o folheto explicativo.

O resultado da TANU é colocado no "Diplominha do bebê", documento com todas as informações sobre o nascimento da criança e que é entregue pela maternidade às mães.

É importante salientar que o programa de triagem auditiva é conduzido por fonoaudiólogos; portanto, além dos aspectos audiológicos, quando necessário, a família também recebe orientações sobre os demais aspectos que a Fonoaudiologia aborda, como ocorre nos casos de presença de síndromes e anomalias crânio-faciais. Nessas situações são realizados os encaminhamentos necessários. 



\section{REFERÊNCIAS}





\section{REFERÊNCIAS}

1. American Academy of Pediatrics Task Force on Newborn and Infant Hearing: Newborn and Ifant hearing loss: Detection and intervention. Pediatr. 1999;103:527-30.

2. Arnold CL, Davis TC, Frempong JO, Humiston SG, Bocchini A, et al. Assessment of newborn screening parent education materials. Pediatrics. 2006 May;117(5 Pt 2):S320-5.

3. Arnold CL, Davis TC, Humiston SG,Bocchini JA Jr, Bass PF 3rd, Bocchini A, Kennen EM, White K, Forsman I. Infant hearing screening: stakelordes recommendation for parent-centered communication. Pediatrics. 2006;117(5 Pt 2):S341-54.

4. Babbie ER. The practice of social research. $10^{\text {th }}$ ed. Boston: MA Wadsworth Publishing Company; 2003.

5. Baroch KA. Universal newborn hearing screening: fine-tuning the process. Curr Opin Otolaryngol Head Neck Surg. 2003;11(6):424-7.

6. Chapchap MJ. Grupo de apoio à triagem auditiva neonatal universal-Quanto antes, melhor. Rev Fonoaud. 2005;62:17-20.

7. Chapchap MJ, Segre CM. Universal newborn hearing screening and transient evoked otoacoustic emission: new concepts in Brasil. Scand Audiol. 2001;30:339.

8. Clemens CJ, Davis SA, Bailey AR. The false-positive in universal newborn hearing screening. Pediatrics. 2000. [acesso em: jul. 2005]; Disponível em: http://www.pediatrics.org/cgi/content/full/106/1/e7.

9. Comitê brasileiro sobre perdas auditivas na infância (CBPAI). Jornal do CFF . 2000;5:3-7.

10. Crockett R, Baker H, Uus K, Bamford J, Marteau TM. Maternal anxiety and satisfaction following infant hearing screening: a comparison of the health visitor distraction test and newborn hearing screening. J Med Screen. 2005;12(2):78-82.

11. Crockett R, Wright AJ, Uus K, Bamford J, Marteau TM. Maternal anxiety following newborn hearing screening: the moderating role of knowledge. J Med Screen. 2006;13(1):20-5.

12. Declau, F; Doyen, A; Robillard, T; de Varebeke, SJ. Universal newborn hearing screening. B-ENT. 2005;1:16-21.

13. DesGeorges, J. Family perceptions of early g, detection, and intervention systems: listening to and learning from families. Ment Retard Dev Disabil Res Rev. 2003;9(2):89-93. 
14. Gomes de Oliveira C. Lelis I. Tensões e intenções da pesquisa. Procedimentos metodológicos - os caminhos percorridos. Diga-me com quem andas e eu te direi quem és. A escolha da escola como estratégia de distinção. 2004. Certificação Digital No 0212094/CA [dissertação]. Rio de Janeiro:Pontifícia Universidade Católica do Rio de Janeiro; 2004. Disponível em: www.maxwell.lambda.ele.pucrio.br/cgi-bin/ PRG_0599.EXE/6069_3.PDF?NrOcoSis=16900\&CdLinPrg=pt. Acesso em: Mar/2006.

15. Gracey K. Current concepts in universal newborn hearing detection and intervention programs. Adv Neonatal Care. 2003;3(6):308-17.

16. Günther H. Como elaborar um questionário. In: Pasquali L. (org.) instrumentos psicológicos: manual prático de elaboração. Brasília: LabPAM; 1999:231-258.

17. Hergils L, Hergils A. Universal neonatal hearing screening-parental attitudes and concern. Br J Audiol. 2000;34(6):321-7.

18. Hyde ML. Newborn hearing screening programs: overview. J Otolaryngol. 2005;34 (Suppl 2):S70-8.

19. Joint Committee on Infant Hearing ( JCIH) position statement. ASHA. 1994;36:38-41.

20. Joint Committee on Infant Hearing ( JCIH) position statement: principles and guindelines for early hearing detection and intervention programs. ASHA. 2000;9:9-29.

21. Kemp DT. Stimulated acoustic emissions from within the human auditory system. J Acoustic Soc Am. 1978;64:1386-91.

22. Luterman D, Kurtzer-White E. Identifying hearing loss: parent's needs. Am J Audiol. 1999;8(1):13-8.

23. Luterman D, Kurtzer-White E. Families and children with hearing loss: grief and coping. Ment Retard Dev Disabil Res Rev, 2003;9(4):232-5

24. Manfredi AKS. Intervenção fonoaudiológica junto às mães ou responsáveis por recém-nascidos de risco para deficiência auditiva com vistas à detecção precoce. [dissertação], São Paulo:Escola de Enfermagem de Ribeirão Preto, Universidade de São Paulo, 2001.

25. Ministério da Saúde, Secretaria de Atenção à Saúde (on line). Política Nacional de Saúde Auditiva. 2004. [acesso em: nov. 2005]. Disponível em: http://www.saude.gov.br/sas.

26. National Institutes of Health (NIH) consensus statement. Early identification of hearing impairment in infants and young children. NIH. Consensus Statement. $1993 ; 11: 1-24$.

27. Ng PK, Hui Y, Lam BC, Goh WH, Yeung CY. Feasibility of implementing a universal neonatal hearing screening programe using distortion product 
otoacoustic emission detection at a university hospital en Hong Kong. Hong Kong Med J, 2004;10(1):6-13.

28. Northen JL, Downs MP. Audição em crianças. $3^{\text {a }}$ ed. São Paulo: Manoele; 1989.

29. Oliveira TMT, Zanelli AC, Mainardi J. Conhecimento e atitudes das mães frente à triagem auditiva neonatal universal. Fonoaudiologia Brasil. 1998;1(3):18-21.

30. Picton N, Hyde M. Family anxiety and universal newborn hearing screening (UNHS): a review of current evidence. 2004 [acesso em 12 janeiro de 2006]. Disponível em: http://childhearingroup.isib.cnr.it/docs/unhs_and family_anxiety.pdf.

31. Pipp-Siegel S, Sedey AL, Yoshinaga-Itano C. Predictors of parental stress in mothers of young children with hearing loss. J Deaf Stud Deaf Educ. 2002;7(1):117 .

32. Poulakis Z, Barker M, Wake M. Six month impact of false positives in an Australian infant hearing screening programme. Arch Dis Child. 2003;88:20-4; [acesso em: ago. 2005]. Disponível em: http://adc.bmjjournals.com/cgi/reprint/88/1/20.

33. Ribeiro FG. Da triagem auditiva neonatal ao diagnóstico: os pais diante da suspeita de deficiência auditiva no filho [dissertação]. São Paulo (SP): Pontifícia Universidade Católica de São Paulo; 2005.

34. Russ SA, Kuo AA, Poulakis Z, Barker M, Rickards F, Saunders K, et al.. Qualitative analysis of parents' experience with early detection of hearing loss. Arch Dis Chil 2004;89:353-8. [acesso em: dez. 2005]. Disponível em: http://adc.bmjjournals.com/cgi/content/full/89/4/353.

35. Stool S. Identificação do recém-nascido. IV Manual of Pediatrics Otorhinolaryngology IAPO/IFOS. 2004; [acesso em: fev. 2006]. Disponível em: http://www.iapo.org.br/port/manual/2004manual/audicao/02pdf.

36. Stuart A, Moretz M, Yang EY. An investigation of maternal stress after neonatal hearing screening. Am J Audiol. 2000;9(2):135-41.

37. Vohr BR, Letouneau KS, McDermott C. Maternal worry about neonatal hearing screening. J Perinatol. 2001;21(1):15-20.

38. Vohr BR, Moore PE, Tucker RJ. Family health insurance and other environmental factors on universal hearing screen program effectiveness. J Perinatol. 2002;22(5):380-5.

39. Weber J, Diefendorf A. Triagem auditiva neonatal. In: Musiek FE. Perspectivas atuais em avaliação auditiva. Barueri : Manoele; 2001:323-38.

40. Weichbold V, Welzl-Muller K. Universal neonatal hearing screening-attitude and fears of mothers. HNO. 2000;48(8):606-12. 
41. Weichbold V, Welzl-Muller K. Maternal concern about positive test results in universal newborn hearing screening. Pediatrics. 2001;108(5):1111-6.

42. White KR, Vohr BR, Behrs TR. Universal newborn hearing screening program using transient evoked otoacoustic emissions. Semin Hear. 1993;14(1):1-24.

43. Yoshinaga-Itano, C. The social-emotional ramifications of universal newborn screening, early identification and intervention of children who are deaf or hard of hearing. 2001 [acesso em dez. 2005]. Disponível em:

http://www.colorado,edu/slhs/mdnc/research/publications/itano26.html.

44. Yoshinaga-Itano C, Sedey AL, Coulter DK, Mehl AL. Language of early-andlater-identified child with hearing loss. Pediatrics. 1998;102(5):1161-71.

45. Young A, Andrews E. Parent's experience of universal neonatal hearing screening a critical review of the literature and its implications for the implementation of new UNHS programs. J Deaf Stud Deaf Educ. 2001;6(3):149-60

46. Young A, Tattersall H. Parent's of deaf children evaluative accounts of the process and practive of universal newborn hearing screening. J Deaf Stud Deaf. Educ. 2005; 10(2):134-45.

47. Tanaka O, Melo C. Como elaborar um questionário para coletar informações quantitativas. Avaliação de programas de saúde do adolescente: um modo de fazer. São Paulo: Edusp, 2001 [acesso em mar. 2006]. Disponível em: http://www.bireme.br/bvs/adolec/P/textocompleto/adolescente/capitulo/cap10.htm 
ABSTRACT 



\section{ABSTRACT \\ Audiology intervention along to the family during the universal newborn hearing screening}

The universal newborn hearing screening - UNHS - has been recommended in Brazil and other foreign countries as the main instrument to assure, in the first years of life, the diagnosis of the auditory deficiency. In this measure, the goal of the current study was to identify the worry and knowledge degrees concerning to this procedure regarding the familiar people, aiming to contribute for the planning of actions that make possible audiologist guidance strategies even more efficient. It was also possible to observe how much the parents know about the baby hearing, and what can be taken to create more welcoming ways of attendance and attention to the real necessities of the family during the audiologist diagnosis. For the research, 42 families were initially selected, for those 38 remained, whose babies did not pass in the UNHS test and retest, which were held at the Maternity Saint Isabel - Bauru/SP, for the project "Auditory Health Model in the Newborn". Data and registers collecting were carried through the Audiologist Infantile Clinic of the Therapy Speech-Audiologist Department at FOBUSP, Bauru/SP, over the application of an integrally adapted instrument, based on two questionnaires: the Rhode Island Hearing Screen Program Questionnaire, applied in Rhode Island Hearing Assessment Program; and the questionnaire applied for HERGILS; HERGILS ${ }^{17}$, 2000 in the University Hospital, Linköping-Sweden. Six questions were included by the judges that validated the instrument. The results showed a significant increase of the maternal concern degree between the UNHS test and retest $(\mathrm{p}=0,002)$; most of the participants $(50 \%)$ was informed about UNHS procedures after the hospital discharge, 34\% during hospital admission and 16\% before the hospital admission; 55\% informed that they did not know the professional name that performed the UNHS procedures; $100 \%$ declared to be for to the UNHS program. From all participants, $53 \%$ confirmed unsatisfied with the received information, not only on the objectives but also on the consequences of the evaluation. The recent study confirmed the results of other researches that point out the importance of the Auditory Health programs in order to assure that the families understand the necessity of the UNHS procedures, as well as the continuation of the audiologist diagnosis and previous intervention, when necessary.

Keywords: Screening newborn. Hearing Tests Family. Questionnaires. 